\title{
Synthesis of migrastatin analogues as inhibitors of tumour cell migration: exploring structural change in and on the macrocyclic
} ring.

\author{
Daniele Lo Re, ${ }^{[a]}$ Ying Zhou, ${ }^{[a]}$ Joanna Mucha, ${ }^{[c]}$ Leigh F. Jones, ${ }^{[a]}$ Lorraine C. Leahy, ${ }^{[b]}$ Corrado \\ Santocanale, ${ }^{[b]}$ Magdalena Krol ${ }^{[c]}$ and Paul V. Murphy, ${ }^{*[a]}$ \\ Dedication ((optional))
}

\begin{abstract}
Migrastatin and isomigrastatin analogues have been synthesised in order to contribute to structure-activity studies on tumour cell migration inhibitors. These include macrocycles varying in ring size, functionality and alkene stereochemistry, as well as glucuronides (macrolides). The synthesis work included application of Saegusa-Ito reaction for regio- and stereoselective unsaturated macroketone formation, diastereoselective Brown allylation to generate 9methylmigrastatin analogues and chelation induced anomerisation to vary glucuronide configuration. Compounds were tested in vitro against both breast and pancreatic cancer cell lines and inhibition of tumour cell migration was observed in both wound-healing (scratch) and Boyden chamber assays. One unsaturated macroketone showed low affinity for a range of secondary drug targets, indicating it is at low risk of displaying adverse side effects
\end{abstract}

\section{Introduction}

Tumour metastasis is a process where cancer cells detach from a primary tumour, migrate and then colonize a distant organ and the process leads to mortality for cancer patients. ${ }^{[1]}$ Small molecules that interfere with tumour cell migration ${ }^{[2]}$ have significant potential as anti-metastatic drugs ${ }^{[3]}$ or as tools ${ }^{[4]}$ for the study of tumour cell migration. Migrastatin 1, is a natural product that inhibits tumour cell migration ( $\mu \mathrm{M}$ range) in vitro. Truncated ${ }^{[5]}$ or simpler analogues of migrastatin, such as 2, 3, MGSTA-4 and MGSTA-5 (Figure 1), prepared in Danishefsky's laboratory, ${ }^{[6]}$ have been reported to show orders of magnitude higher activity than migrastatin itself in vitro and both $\mathbf{3}$ and MGSTA-5 ${ }^{[7]}$ and other compounds ${ }^{[8]}$ have demonstrated inhibitory activity in vivo. We have been engaged in the synthesis of migrastatin analogues ${ }^{[9]}$ and recently through collaboration with Anderson and Nobis have shown that macroketone MGSTA-5 inhibited E-cadherin dynamics in vivo, in

[a] School of Chemistry, National University of Ireland E-mail: paul.v.murphy@nuigalway.ie

[b] National Centre for Biomedical Engineering Science, National University of Ireland, Galway

[c] Department of Physiological Sciences, Faculty of Veterinary Medicine, Warsaw University of Life Science, Warsaw, Poland

Supporting information for this article is given via a link at the end of the document.((Please delete this text if not appropriate)) a manner consistent with increased cell adhesion and reduced invasive potential. ${ }^{10]}$ It has been reported that the target for MGSTA-5 is fascin, which is recognized as being involved in cell motility and migration processes and is upregulated in many human tumours as well as in several cancer cell lines including breast ${ }^{[11]}$, pancreatic. ${ }^{[12]}$ and colon cancer cells. ${ }^{[13]}$ Importantly, fascin is also involved in the chemotherapeutic resistance of breast. ${ }^{[14]}$ and colon ${ }^{[15]}$ cancer cells. However, whether fascin is the target for MGSTA-5 is still debated ${ }^{[16]}$ and there is a belief that there may be other unidentified target(s) of migrastatin and its analogues. ${ }^{[16]}$

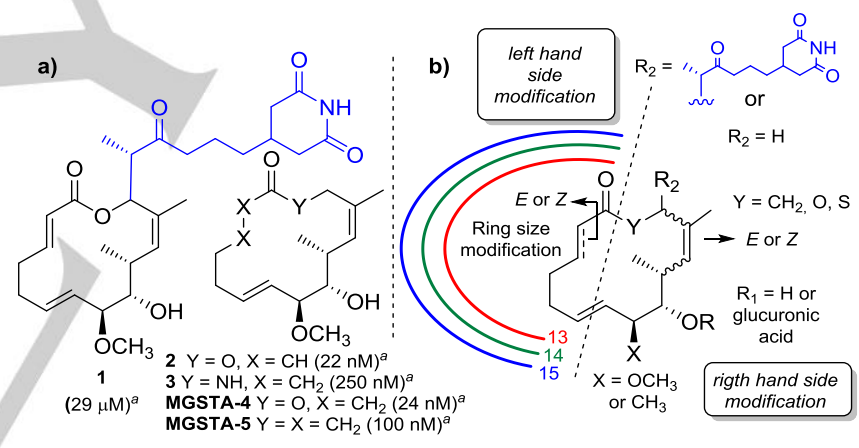

Figure 1. a) Migrastatin (1) and truncated analogues 2-3 $I_{50}$ values (in parentheses) in Boyden chamber assay against $4 \mathrm{~T} 1$ mouse mammary cancer cells. ${ }^{\left[{ }^{6}\right]}$ b) Modification of migrastatin-core in this paper

For these reasons the synthesis of analogues of migrastatin, including new analogues, continues to be of interest ${ }^{[6,8,17]}[7,16 \mathrm{~b}$, 18] [19]. Here we report the the preparation and migrastatin analogues shown in Figure 2. The modifications have included variation in macrocycle ring size and functionality within the ring as well as varying alkene geometry and glucuronidation. Included are the syntheses of related isomigrastatin analogues. The reasons for synthesis of these various analogues include attempts to generate analogues to ultimately contribute to the structure-activity relationships and to try to identify more potent analogues. The activity of selected compounds in relevant bioassays was subsequently investigated and results of these are described. 

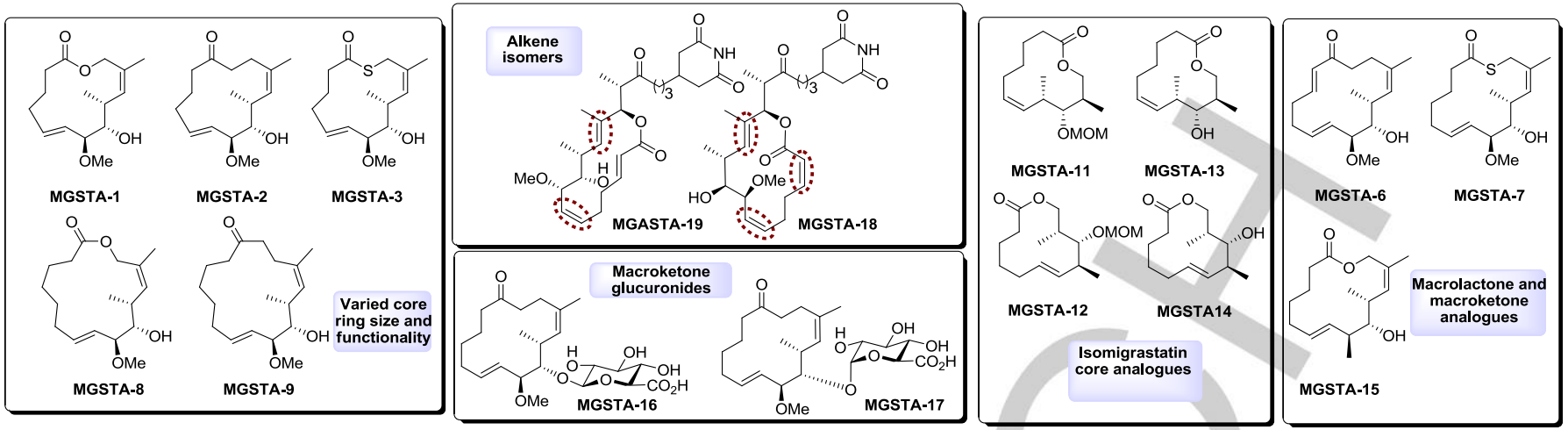

Figure 2. Migrastatin analogues prepared in this manuscript

\section{Results and Discussion}

\section{Modification of the macrocycle structure and ring size}

The synthetic work began from intermediate $\mathbf{5}$, which was prepared in two gram quantity using the route recently developed in our laboratory. ${ }^{[10]}$ This intermediate was first used to prepare 13-15 membered ring structures based on macrolactones, macroketones and macrothiolactones. Firstly, the allylic alcohol $\mathbf{5}$ was coupled to carboxylic acids $\mathbf{6 a - c}$ under Mitsunobu conditions and the esters formed were then treated with the Grubbs-II metathesis catalyst to afford the macrolactones $8 \mathrm{a}-\mathrm{c}$ by ring closing metathesis (RCM). Removal of the TBS group using HF.pyridine gave MGSTA-4 ${ }^{[6]}$ and its new 13 and 15 member analogues MGSTA-1 and MGSTA-8. Macroketones, were prepared via conversion of alcohol 6 into the allylic bromide 9 and subsequently reacting 9 with $\beta$ ketosulfones 10 a-c as previously described ${ }^{[6]}$ to give 11 a-c. Ring closing metathesis followed by TBS removal afforded MGSTA$5^{[6]}$ and new analogues MGSTA-2 and MGSTA-9. Macroketone 12b was reacted with LHMDS and TMSCl to give an enolate which was then oxidized by Saegusa-Ito conditions to afford the $\alpha, \beta$-unsaturated macroketone 13 which after desilylation gave MGSTA-6. Macrothiolactones were prepared via the Mitsunobu reaction of thioacids $\mathbf{1 5 a - b}$ with the allylic alcohol 5 . Thioacids 15a and 15b were firstly readily prepared treating the corresponding carboxylic acid with Lawesson's reagent under microwave irradiation. ${ }^{[20]}$ The thioacids $15 a-b$ were not stable to silica gel and hence were instead purified by distillation under reduced pressure (Kugelrorh, $\mathrm{P}=50 \times 10^{-3} \mathrm{mbar}, \mathrm{T}=45^{\circ} \mathrm{C}, 2 \mathrm{~h}$ ) or were used without distillation in the next step. Coupling of 15a-b to 5 using Mitsunobu conditions, and subsequent RCM and TBS group removal afforded macrothiolactones MGSTA-3 and 7. The compounds MGSTA-1 to 9, were purified using flash chromatography (representative mobile phase: petroleum etherethyl acetate, 1:1). The purifty of these macrocyclic agents could be increased by their distillation under reduced pressure (Kugelrorh, $\mathrm{P}=0.05 \mathrm{mbar}, \mathrm{T}=90^{\circ} \mathrm{C}$, distillation time from $2 \mathrm{~h}$ to 24h).

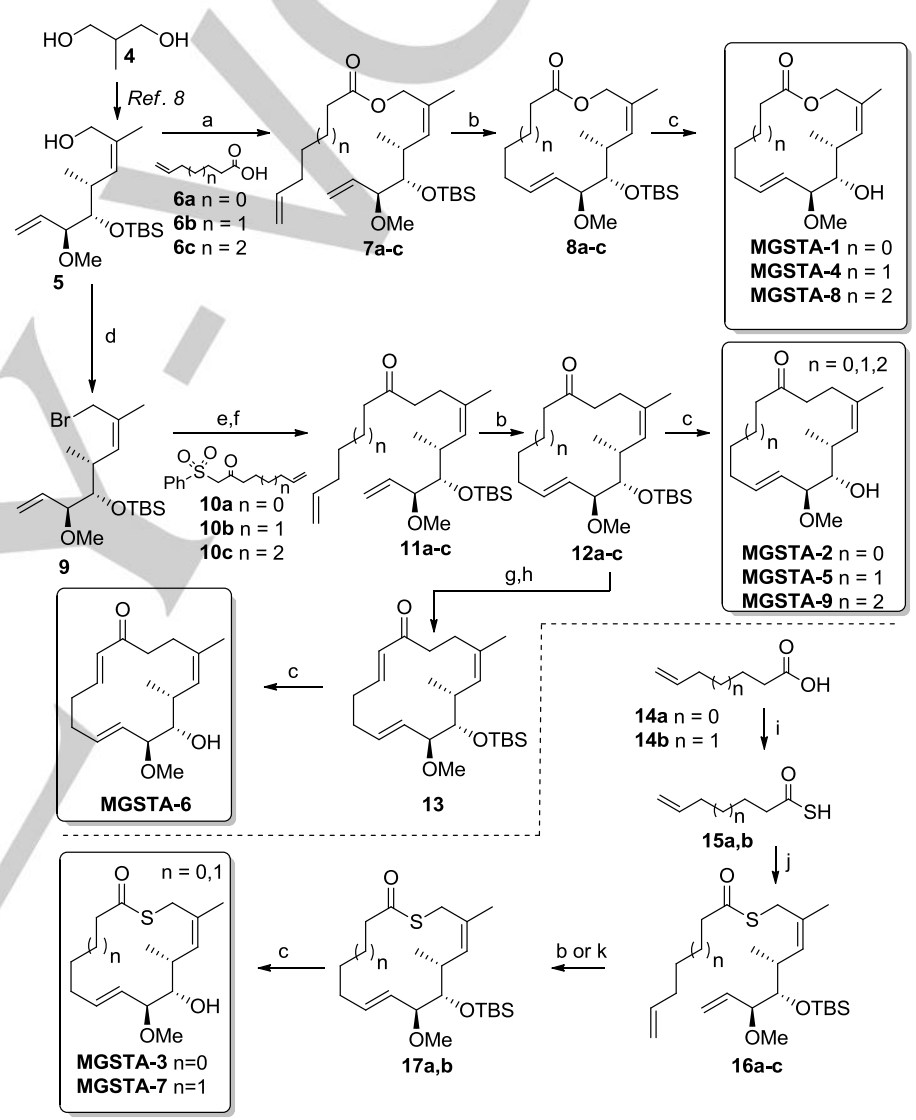

Scheme 1. Synthesis of migrastatin-core analogues. Reagents and conditions: (a) 6a-c, $\mathrm{Ph}_{3} \mathrm{P}, \mathrm{DIAD}, \mathrm{PhCH}_{3}$, rt; 7a (69\%), 7c (76\%) (b) Grubbs-II catalyst, $\mathrm{PhCH}_{3}$, reflux, 8a (68\%), 12a (99\%), 17a (88\%), 8c (73\%), 12c $(60 \%)$ (c) HF.Py, THF, rt; MGSTA-1 (61\%), MGSTA-2 (84\%), MGSTA-3 (85\%), MGSTA-6 (90\%), MGSTA-7 (63\%), MGSTA-8 (54\%), MGSTA-9 (82\%) (d) $\mathrm{CBr}_{4}, \mathrm{Ph}_{3} \mathrm{P}$ polymer-bound, $\mathrm{CH}_{2} \mathrm{Cl}_{2}$; (e) 10a-c, $\mathrm{DBU}, \mathrm{PhCH}_{3}$ then 9, rt, 11a (51\%) 11c (51\%), from 9 (f) $\mathrm{Na} / \mathrm{Hg}, \mathrm{MeOH}$, rt; (g) TMSCI, LHMDS, THF, $0{ }^{\circ} \mathrm{C}$, 2h; (h) $\mathrm{Pd}(\mathrm{OAc})_{2}, \mathrm{CH}_{3} \mathrm{CN}$, rt, $2 \mathrm{~h}, 78 \%$ from 12b; (i) Lawesson's reagent, $\mathrm{CH}_{2} \mathrm{Cl}_{2}, \mathrm{mw}, 100{ }^{\circ} \mathrm{C}, 10 \mathrm{~min}$; (j) 15a,c, $\mathrm{Ph}_{3} \mathrm{P}, \mathrm{DIAD}, \mathrm{PhCH}_{3}$, rt; 16a (42\%), 16b (39\%) (k) Grubbs-II catalyst, $\mathrm{CH}_{2} \mathrm{Cl}_{2}$, mw, $100^{\circ} \mathrm{C}, 30 \mathrm{~min}, 17 \mathrm{~b}(49 \%)$, 
Isomigrastatin 18, a natural product isolated from Streptomyces platensis ${ }^{[21]}$ and a precursor to migrastatin and it is a potent inhibitor of tumour cell migration. ${ }^{[17 d]}$ In view of this, we have used monoprotected diol 19 , readily available in 4 steps from $4{ }^{[10]}$ for the preparation of truncated isomigrastatins. Firstly the direct exchange of the $\mathrm{OH}$ in $\mathbf{1 9}$ for $\mathrm{Br}$ was attempted, but when 19 was treated with polymer bound $\mathrm{Ph}_{3} \mathrm{P}$ and $\mathrm{CBr}_{4}$ in $\mathrm{CH}_{2} \mathrm{Cl}_{2}$, the methoxy group at $\mathrm{C}-4$ migrated to the $\mathrm{C}-1$ position giving allylic bromide 20 (68\%), with no trace of the desired compound being found. Attempts to form the tosylate or chloride from 19 led to complex reaction mixtures. On the other hand, when 19 was coupled with carboxylic acid $\mathbf{6 b}$ under Mitsunobu conditions the desired ester $\mathbf{2 2}$ was isolated in a $57 \%$ yield together with a small amount of rearranged compound 21 (14\%). With 22 in hand, RCM was next attempted. Unfortunately, reaction of 22 with the Grubbs-II in toluene only gave a complex mixture (TLC evidence) and the desired product was not detected (MS and ${ }^{1} \mathrm{H}-\mathrm{NMR}$ spectroscopic evidence). The TBS group was removed from 22 and the secondary alcohol generated then protected as the MOM ether 23. In this case, 23 readily cyclized using Grubb's $2^{\text {nd }}$ to afford macrocycle 24 (Scheme 2) as previously described. ${ }^{[22]} A$ mechanistic proposal for formation of $\mathbf{2 0}$ and 21 is suggested in Scheme $2 \mathrm{~B}$. benzoate group enabling diol $\mathbf{2 6}$ to be isolated in moderate yield; the relative configuration was determined by obtaining an X-ray crystal structure determination for 26 . Diol 26 was then protected as its di-O-TBS ether and subsequent treatment with $10 \% \mathrm{TsOH}$ in $\mathrm{MeOH}$ removed the TBS group from the primary position to give the alcohol 27. This alcohol 27 was oxidized with the Dess-Martin periodinane and the aldehyde obtained was then treated with the Ando phosphonate ${ }^{[17 \mathrm{~b}, 17 \mathrm{k}, 24]} \mathbf{3 5}$ to give 28. Reduction of the ester group in $\mathbf{2 8}$ using DIBAL-H gave a primary alcohol and its subsequent Mitsunobu reaction gave 29. However, RCM of $\mathbf{2 9}$, under several conditions and reaction time, only gave complex reaction mixtures (TLC) with no trace of the desired product. Alcohol $\mathbf{3 2}$ was prepared with a view to resolving this problem and for application in isomigrastatin analogue synthesis. Since the presence of the TBS group was problematic in the attempted RCM with compound 22, the secondary alcohol was protected as its MOM ether Regioselective protection of the primary alcohol in $\mathbf{2 6}$ with a TBDPS group gave $\mathbf{3 0}$ and subsequent protection of its secondary alcohol as MOM ether afforded the orthogonally protected alkene $\mathbf{3 1}$ which gave $\mathbf{3 2}$ after TBDPS removal.

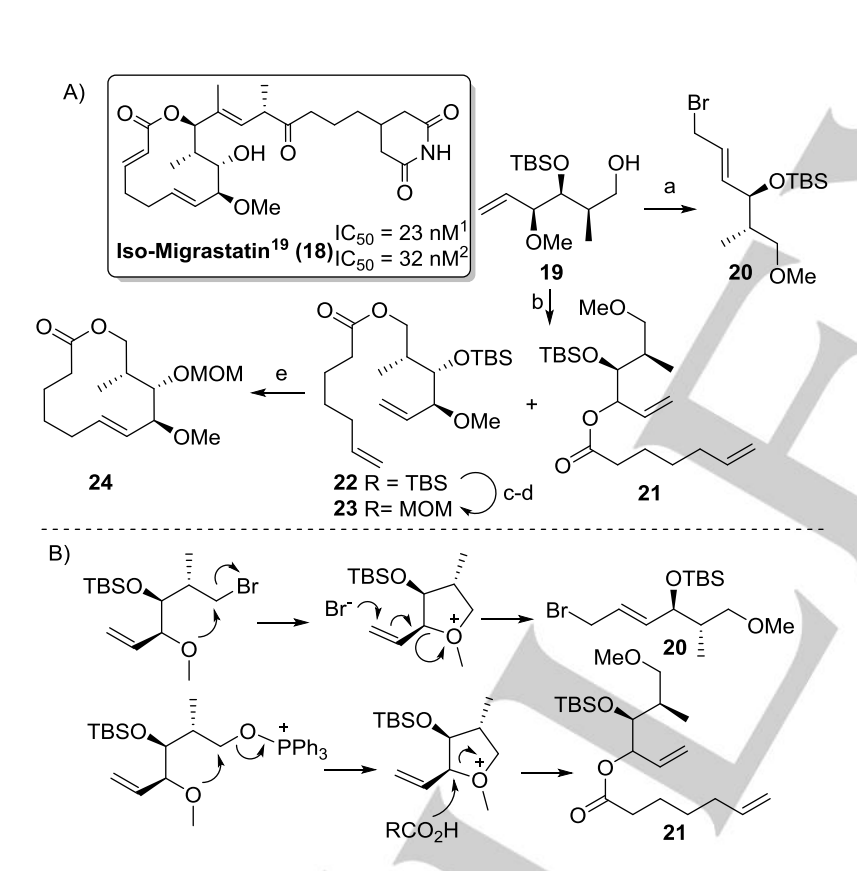

Scheme 2. A) Reagent and conditions: (a) $\mathrm{CBr}_{4}, \mathrm{Ph}_{3} \mathrm{P}$ polymer-bound, $\mathrm{CH}_{2} \mathrm{Cl}_{2}$ rt; 1 h, 68\%; (b) 6b, $\mathrm{Ph}_{3} \mathrm{P}$, DIAD, $\mathrm{PhCH}_{3}$, rt; 57\%; (c) TBAF, THF, rt, 3 days, $60 \%$; (d) $\mathrm{MOMCl}, \mathrm{CH}_{2} \mathrm{Cl}_{2}$, Hunig's base, $0^{\circ} \mathrm{C}$ to rt, $18 \mathrm{~h}, 60 \%$; (e) Grubbs-II catalyst, $\mathrm{PhCH}_{3}$, reflux; $31 \%{ }^{1} \mathrm{IC}_{50}$ values using $4 \mathrm{~T} 1$ mouse mammary adenocarcinoma cells. ${ }^{2} \mathrm{C}_{50}$ values using MDA-MB-231 human breast adenocarcinoma cells ${ }^{[17 \mathrm{~d}]}$; B) Proposed mechanism for formation of $\mathbf{2 0}$ and $\mathbf{2 1}$ under Mitsunobu and Appel conditions.

\section{Synthesis of 9-methylmacrolactone analogues migrastatin and isomigrastatin.}

of

Brown allylation was used as the key step to generate an analogue bearing a methyl group instead of methoxy group at C9. Thus Brown allylation ${ }^{[23]}$ of $\mathbf{2 5}$ (Scheme 3) with cis-butene and $\beta$-methoxydiisopinocampheylborane installed two contiguous stereocenters with subsequent removal of the
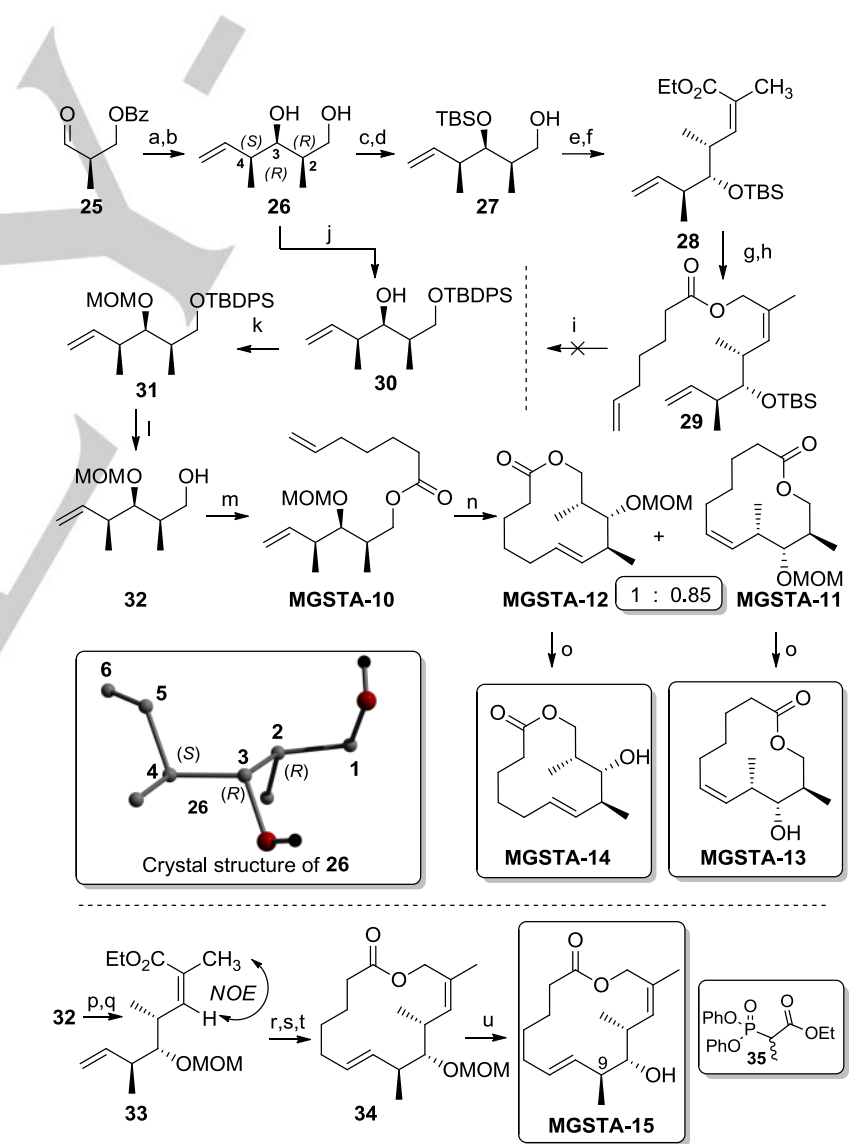

Scheme 3. Synthesis of methyl migrastatin-core analogues. Reagents and conditions: (a) i. cis-Butene, n-BuLi, THF, $45 \mathrm{~min},-20^{\circ} \mathrm{C}$; ii. (+)-lpc2BOMe, 30 min, $-78^{\circ} \mathrm{C}$; iii. $\mathrm{BF}_{3} . \mathrm{Et}_{2} \mathrm{O}$, then 25, 28h; iv. $\mathrm{NaOH} 1 \mathrm{~N}, \mathrm{H}_{2} \mathrm{O}_{2} 30 \%, 16 \mathrm{~h}$; (b) $\mathrm{K}_{2} \mathrm{CO}_{3}, \mathrm{MeOH}, \mathrm{RT}, 24 \mathrm{~h}, 32 \%$ from 25; (c) TBSOTf, DCM, DIPEA, $0^{\circ} \mathrm{C}$, $5 \mathrm{~h}$; (d) p-TSA, MeOH, 3h $0^{\circ} \mathrm{C}, 62 \%$ from 26; (e) DMP, $\mathrm{CH}_{2} \mathrm{Cl}_{2}, \mathrm{RT}, 18 \mathrm{~h}, 88 \%$; (f) 35 THF, $\mathrm{NaH}, 0^{\circ} \mathrm{C}, 1 \mathrm{~h}$, then aldehyde obtained from oxidation of $27,-78^{\circ} \mathrm{C}$ to $\mathrm{RT}$ 18h, 85\%; (g) DIBAL, $\mathrm{CH}_{2} \mathrm{Cl}_{2},-78^{\circ} \mathrm{C}, 10 \mathrm{~min} .63 \%$; (h) $\mathrm{Ph}_{3} \mathrm{P}, \mathrm{DIAD}, 6-$ heptenoic acid, RT, 2h, 81\%; (i) Grubbs-Il catalyst, $\mathrm{PhCH}_{3}$, reflux; (j) TBDPSCI, imidazole, $\mathrm{CH}_{2} \mathrm{Cl}_{2}$, RT, 62\%; (k) MOMCI, DIPEA, $\mathrm{CH}_{2} \mathrm{Cl}_{2}, \mathrm{RT}, 48 \mathrm{~h}, 89 \%$; (I) TBAF $1 \mathrm{M}$, THF, RT, 18h, 98\%; (m) $\mathrm{Ph}_{3} \mathrm{P}$, DIAD, 6-heptenoic acid, RT, 4h, $88 \%$; (n) Grubbs-II catalyst, $\mathrm{PhCH}_{3}, 1 \mathrm{~h}$, heat at reflux, 33\% MGSTA-12 \& $31 \%$ MGSTA-11; (o) TMSBr, $\mathrm{CH}_{2} \mathrm{Cl}_{2},-20^{\circ} \mathrm{C}$, 2h $77 \%$ (MGSTA-13), $74 \%$ (MGSTA14); (p) DMP, $\mathrm{CH}_{2} \mathrm{Cl}_{2}$, pyridine, $\mathrm{RT}, 4 \mathrm{~h}, 70 \%$; (q) $35, \mathrm{THF}, \mathrm{NaH}, 0^{\circ} \mathrm{C}, 1 \mathrm{~h}$, then 
aldehyde obtained from the oxidation of $32,-78^{\circ} \mathrm{C}$ to $\mathrm{RT}, 15 \mathrm{~h}, 73 \% ;(\mathrm{r})$ DIBAL, $\mathrm{CH}_{2} \mathrm{Cl}_{2},-78^{\circ} \mathrm{C}, 15$ min. 76\%; (s) $\mathrm{Ph}_{3} \mathrm{P}$, DIAD, 6-heptenoic acid, RT, 3h, $78 \%$; (t) Grubbs-II catalyst, $\mathrm{PhCH}_{3}$, benzoquinone, $80^{\circ} \mathrm{C}, 5 \mathrm{~h}, 13 \%$; (u) $\mathrm{TMSBr}$, $\mathrm{CH}_{2} \mathrm{Cl}_{2},-20^{\circ} \mathrm{C}$, 3h, $60 \%$.

The Mitsunobu reaction of $\mathbf{3 2}$ gave MGSTA-10. Ring-closing metathesis of MGSTA-10 afforded cis and trans alkene containing macrocycles MGSTA-11 and MGSTA-12 in a 1:0.85 ratio. The MOM protecting group was removed from both intermediates using $\mathrm{TMSBr}$ to give truncated isomigrastatin analogues MGSTA-13 and MGSTA-14. For the synthesis of migrastatin-core analogue MGSTA-15 bearing the methyl group at C-9, the primary alcohol $\mathbf{3 2}$ was oxidized using the DessMartin periodinane, and then treated with the Ando phosphonate ${ }^{[17 \mathrm{~b}, 17 \mathrm{k}, 24]} 35$ giving the trisubstituted alkene 33 , with the $Z$ configuration. The configuration of the newly formed double bond was supported by NOE spectroscopic experiments, where NOEs were observed for $\mathbf{3 3}$ as indicated in Scheme 3. The reduction of $\mathbf{3 3}$ with DIBALH and subsequent esterification using Mitsunobu conditions gave the RCM precursor to S6. As for 29 , the RCM reaction of this precursor was unsuccessful and macrocyclic product could not be detected under several reaction conditions. Fortunately, addition of 1,4-benzoquinone ${ }^{[25]}$ to the reaction mixture led to formation of desired $\mathbf{3 4}$ in modest yield, which after deprotection afforded the 9-methylmacrolactone MGSTA-15.

\section{Synthesis of migrastatin glucuronides}

Glucuronides are an important class of phase 2 metabolites and glucuronidation in vivo of small molecules usually leads to compounds with higher water solubility, which are more easily excreted through the kidney. ${ }^{[26]}$ Glucuronide metabolites are often biologically inactive but in some cases can display interesting bioactivity. ${ }^{[27]}$ [28] The 6-O-glucuronide of morphine (M6G) displays full agonist properties at the $\mu 1$ opioid receptor and appears to be more potent than morphine itself with fewer side effects. ${ }^{[26,29]}$ In addition, the glucuronide of ezetimibe, a selective inhibitor of cholesterol absorption, is more active than ezetimibe itself. ${ }^{[26]}{ }^{[30]}$ The biological activity of thiocolchicoside, a myorelaxant used for painful muscle contraction, has to be attributed to the presence of the 3-O-glucuronidated aglycone. ${ }^{[26]}$ A glucuronide can be hydrolyzed through an enzymatic or nonenzymatic reaction to give the active aglycon ${ }^{[27]}$ In this latter context glucuronidation has been used as for the preparation of SN-38 and taxol prodrugs. ${ }^{[27,31]}$ The strategy relies on the fact that $\beta$-glucuronidase is generally overexpressed in tumour tissues. In view of these interesting properties of glucuronides and of the possibility that in vivo generation of glucuronides can occur we decided to prepare the glucuronide of MGSTA-5. Thus, MGSTA-5, which had been prepared on $100 \mathrm{mg}$ scale, was coupled with trichloroacetimidate $36^{[32]}$ using TMSOTf affording exclusively the protected $\beta$-glucuronide 37 . Simultaneous removal of benzoate protective groups and hydrolysis of the methyl ester using aqueous $\mathrm{NaOH}$ gave the macroketone $\beta$-glucuronide MGSTA-16. In order to obtain the $\alpha$ anomer of this glucuronide we applied the chelation induced anomerization ${ }^{[33]}$, which has been of interest in our laboratory ${ }^{[33 \mathrm{~d}]}$ for the synthesis of the $\alpha$-glucuronide. Thus, glucuronide $\mathbf{3 7}$ was treated with $\mathrm{TiCl}_{4}$ in $\mathrm{CDCl}_{3}$ at $4{ }^{\circ} \mathrm{C}$ giving the $\alpha$-glucuronide 38 as the only product. Deprotection and ester hydrolysis gave MGSTA-17.

Synthesis of glutarimide containing analogues of migrastatin where alkene geometry is varied.

The preparation of MGSTA-18 and MGSTA-19, containing the glutarimide side-chain, where olefin geometry is modified in the macrocyclic core was included in the synthetic study. Thus, diene precursors were prepared from freshly prepared aldehyde 39 (Scheme 5) using Wittig reagent $\mathbf{4 0}$ to give the E-alkene $\mathbf{4 1}$ with high stereoselectivity $(E: Z=25: 1)$; this reaction provided the isomer which would enable preparation of migrastatin analogues with an E-alkene at C-3 in the macrocycle. The subsequent steps were similar to those used by Danishefsky and coworkers $^{[6,17 \mathrm{~h}]}$ for their preparation of migrastatin. Thus, the reduction of the ester with DIBAL-H gave the corresponding allylic alcohol which was subsequently oxidized using the DessMartin reagent and the aldehyde generated was reacted with propionyl oxazolidinone 42 in the presence of $\mathrm{MgCl}_{2}$, triethylamine, and TMSCl to afford, after treatment with TFA, the desired anti-aldol product 43. Protection of the hydroxy group as a TES ether, and reductive removal of the auxiliary gave primary alcohol $\mathbf{4 4}$ in good yield (Scheme 5). The glutarimide aldehyde 47 needed for the introduction of the glutarimide chain was prepared from 45 via thioester 46 (Scheme 5). ${ }^{[34]}$

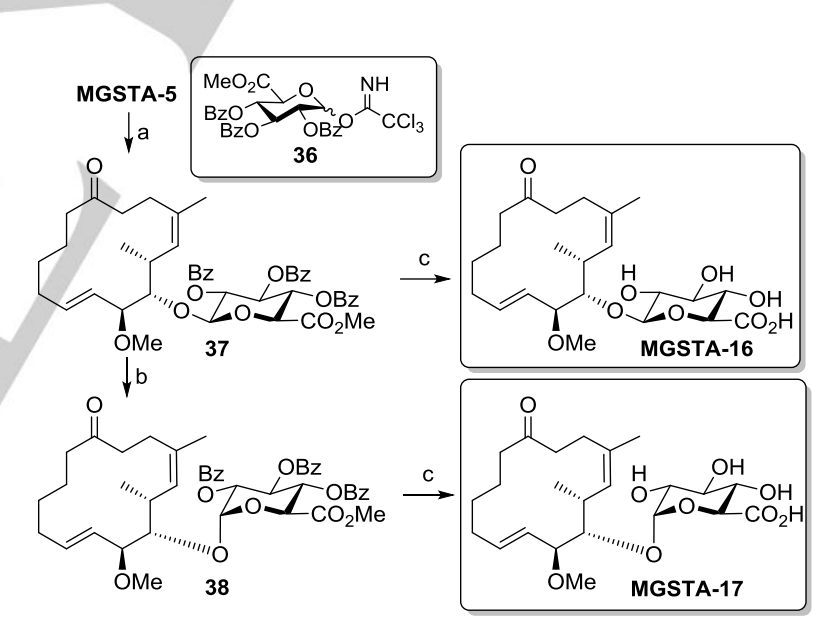

Scheme 4. Reagents and conditions: (a) 36 TMSOTf, MS (AW300), $\mathrm{CH}_{2} \mathrm{Cl}_{2},-78{ }^{\circ} \mathrm{C}, 5 \mathrm{~h}, 60 \%$; (b) $\mathrm{TiCl}_{4}, \mathrm{CDCl}_{3}, 4{ }^{\circ} \mathrm{C}, 69 \%$; (c) $\mathrm{NaOH}$ aq., $\mathrm{MeOH}$, rt, 18h, MGSTA-17 (61\%), MGSTA-16 (73\%).

With 44 in hand the preparation of $\mathbf{5 1}$ was next completed. Hence Dess-Martin oxidation of $\mathbf{4 4}$ gave the corresponding aldehyde which was reacted with the anion generated by reaction of dimethyl methylphosphonate with butyl lithium to give an alcohol intermediate. Oxidation of this alcohol afforded phosphonate 48. Then glutarimide aldehyde $\mathbf{4 7}$ was treated with 48 using the Masamune-Roush variant of the HornerWadsworth-Emmons reaction, giving the corresponding E-enone which was reduced with the Stryker reagent $\mathbf{5 0}$ and subsequent selective cleavage of TES protecting group gave alcohol 49 (Scheme 6). The synthesis of stereoisomers of migrastatin was possible with $\mathbf{4 9}$ in hand, as it had a trisubstituted alkene with 
the E-configuration (Scheme 6). Thus the modified Yamaguchi acylation from 2,6-heptadienoic acid gave 51. However, the subsequent RCM reaction, attempted using both the Grubbs-II and Hoveyda-Grubbs-II catalysts, did not give rise to a ring closed product. The coupling of $\mathbf{4 9}$ with 6 -heptenoyl chloride, which gave $\mathbf{5 2}$ was carried out. Substrate $\mathbf{5 2}$ does not contain the unsaturated ester and in this case the RCM reaction succeeded and gave the ring closed product as a mixture of $E$ and Z-stereoisomers (2:1), which were difficult to separate. Removal of the TBS group from the mixture was effectively achieved using HF-pyridine to give both 53a and 53b. The presence of both Z:E isomers in the mixture was deduced by alkene proton signals in the ${ }^{1} \mathrm{H}-\mathrm{NMR}$ spectrum of the mixture of 53a and 53b with coupling constants $J=10.7 \mathrm{~Hz}(Z)$ and $\mathrm{J}=$ $15.2 \mathrm{~Hz}(\mathrm{E})$.
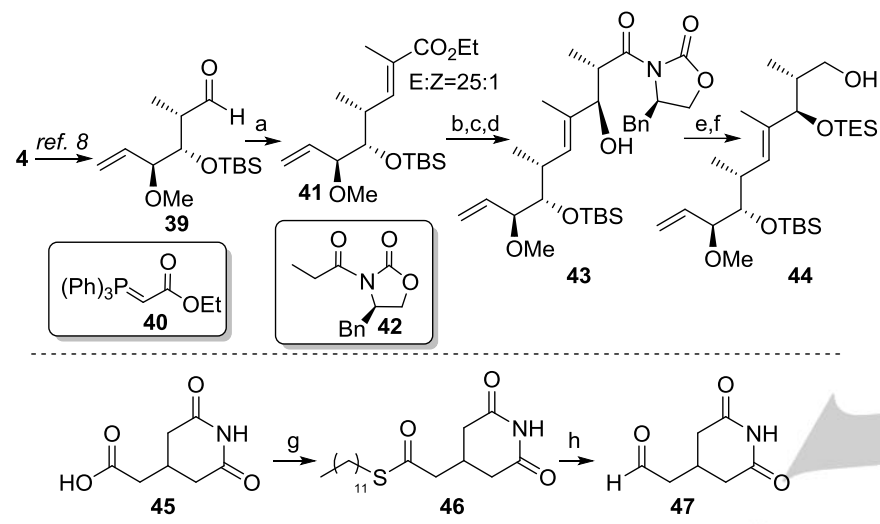

Scheme 5. Reagents and conditions: (a) 40, $\mathrm{PhCH}_{3}$, reflux, 22h, 96\%; (b) DIBAL, $\mathrm{CH}_{2} \mathrm{Cl}_{2}$, $-78^{\circ} \mathrm{C}, 2 \mathrm{~h}, 84 \%$; (c) Dess-Martin, $\mathrm{CH}_{2} \mathrm{Cl}_{2}$, pyridine, $18 \mathrm{~h}, 92 \%$; (d) 42, $\mathrm{MgCl}_{2}, \mathrm{Et}_{3} \mathrm{~N}$, TMSCl, rt, 48h then TFA, MeOH; (e) TESCl, $\mathrm{CH}_{2} \mathrm{Cl}_{2}$, imidazole, rt, $12 \mathrm{~h}, 88 \%$ over two steps; (f) $\mathrm{LiBH}_{4}, \mathrm{MeOH}, \mathrm{THF}, \mathrm{rt}, 1 \mathrm{~h}, 86 \%$; (g) $\mathrm{N}$-methylimidazole, $\mathrm{TsCl}, \mathrm{MeCN}$ then 1-dodecanthiol, 70 min. $0^{\circ} \mathrm{C}, 80 \%$; (h) $\mathrm{Pd} / \mathrm{C} 10 \%, \mathrm{Et}_{3} \mathrm{Si}$, acetone, RT, 1h, 91\%.

Encouraged that the presence of the E-alkene in $\mathbf{5 2}$ did not totally preclude macrocycle formation by RCM, we revised the approach to MGSTA-18 and MGSTA-19. Danishefsky and his co-workers, in their total synthesis of isomigrastatin, ${ }^{[35]}$ reported that RCM gave the 12-membered ring only when the alkene group adjacent to the carbonyl group was absent. They used an a-phenylselenide derivative and introduced the alkene adjacent to the carbonyl group after RCM. In order to obtain MGSTA-18 and MGSTA-19 the selenium containing acid $\mathbf{5 5}$ was therefore first prepared from commercially available $\mathbf{5 4}$ in two steps. Yamaguchi acylation of $\mathbf{4 9}$ with racemic 55 and subsequent removal of the TBS group provided a mixture of diastereoisomers 56. The RCM from 56 using the Grubbs-II reagent gave a 1:2 mixture of $E$-isomer 57 a (not shown) and the Z-isomer $\mathbf{5 7 b}$. The polarity of $\mathbf{5 7 a}$ and $\mathbf{5 7 b}$ was similar on TLC, but it was possible to separate small amounts of $57 \mathrm{a}$ and $\mathbf{5 7 b}$ through repeated chromatographic purification steps. However, despite repeated chromatography it was not possible to obtain these compounds with high purity at the scale at which the reaction was carried out. Thus the oxidative deselenation of the $Z$-isomer $\mathbf{5 7 b}$ was carried out with the material obtained and this gave the E-isomer MGSTA-19 in $42 \%$ yield, along with $23 \%$ of the Z-isomer MGSTA-18 (Scheme 7).

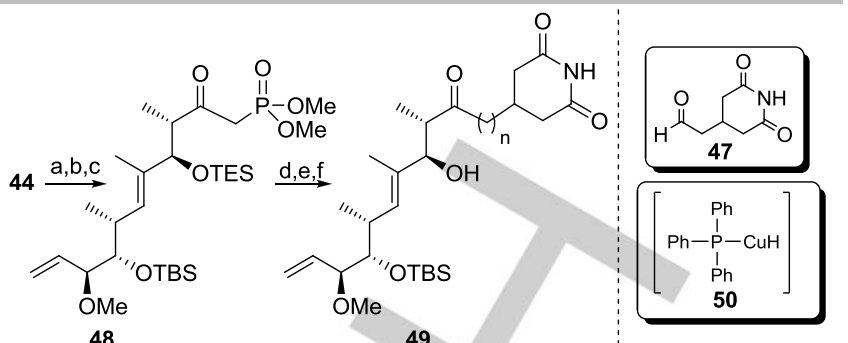

48

49

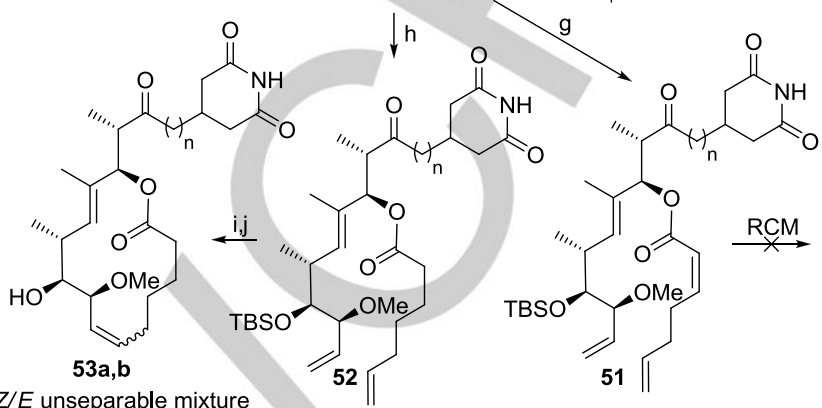

Z/E unseparable mixture

Scheme 6. Reagents and conditions: (a) Dess-Martin, $\mathrm{CH}_{2} \mathrm{Cl}_{2}, \mathrm{rt}, 1.5 \mathrm{~h}$,(b) dimethyl methylphosphonate, BuLi, $-78^{\circ} \mathrm{C}$ to $0^{\circ} \mathrm{C}, 15$ min.; (c) Dess-Martin, $\mathrm{CH}_{2} \mathrm{Cl}_{2}, \mathrm{rt}, 1 \mathrm{~h}, 69 \%$ over three steps; (d) 47, $\mathrm{LiCl}, \mathrm{DBU}, \mathrm{CH}_{3} \mathrm{CN}, 1 \mathrm{~h}, \mathrm{rt}, 94 \%$; (e) $50, \mathrm{PhCH}_{3}$, rt, $89 \%$. (f) $\mathrm{AcOH}, \mathrm{THF}, \mathrm{H}_{2} \mathrm{O}, \mathrm{rt}, 3 \mathrm{~h}, 97 \%$; (g) $(E)-2,6-$ heptadienoic acid, 2,4,6-thrichlorobenzoyl chloride, DIPEA, pyridine, $\mathrm{PhCH}_{3}$, $88 \%$; (h) 6-heptenoyl chloride, DMAP, $\mathrm{CH}_{2} \mathrm{Cl}_{2}, \mathrm{RT}, 75 \%$; (i) Grubbs-II catalyst, $\mathrm{PhCH}_{3}, 1$ h, reflux, $70 \%$; (j) HF.Py, THF, RT, $75 \%$. 


\section{Biological evaluation of migrastatin-core analogues}

With a variety of congeners now prepared, biological studies were next carried out with the capacity of compounds to inhibit tumor cell migration investigated using both wound healing and

a)
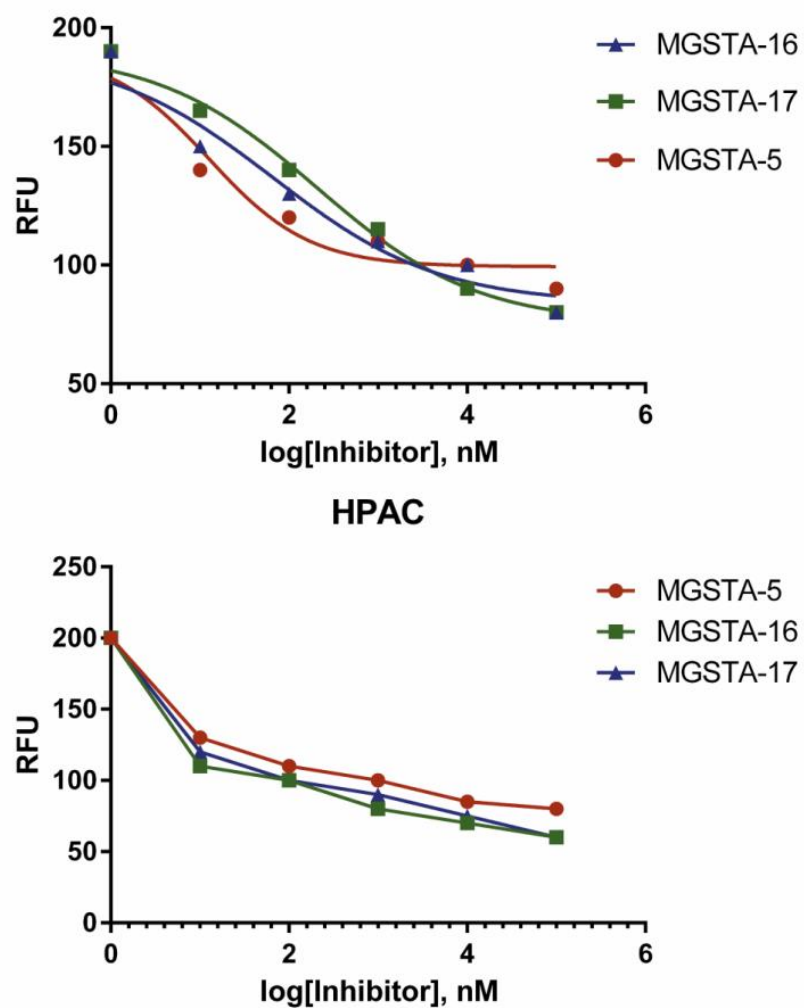

MDA-MB361

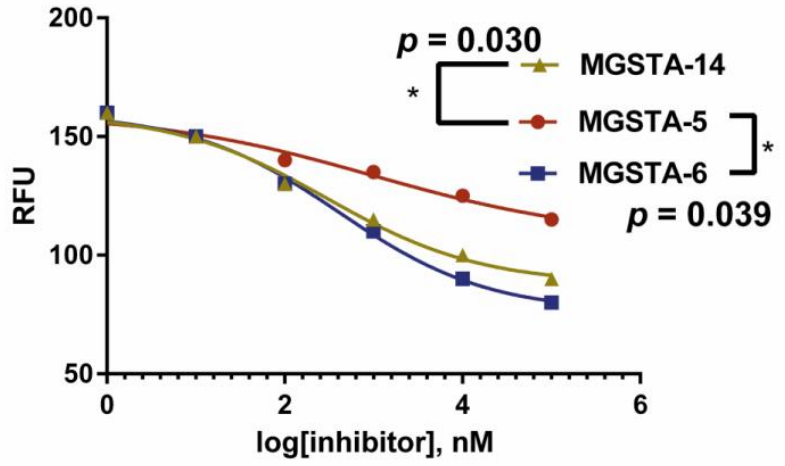

the tested concentrations $(1,10 \& 100 \mu \mathrm{M}$ ) (see supporting information provided). Therefore wound healing assays were next carried out to address the effect on cell migration following exposure to compounds. The migrastatin analogues when given at the concentration of $10 \mu \mathrm{M}$ strongly inhibited migration of the

\section{MCF7}

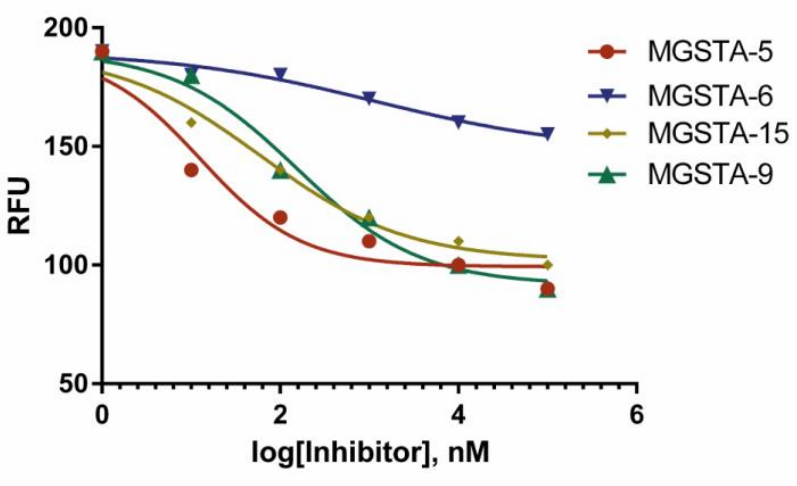

HPAC

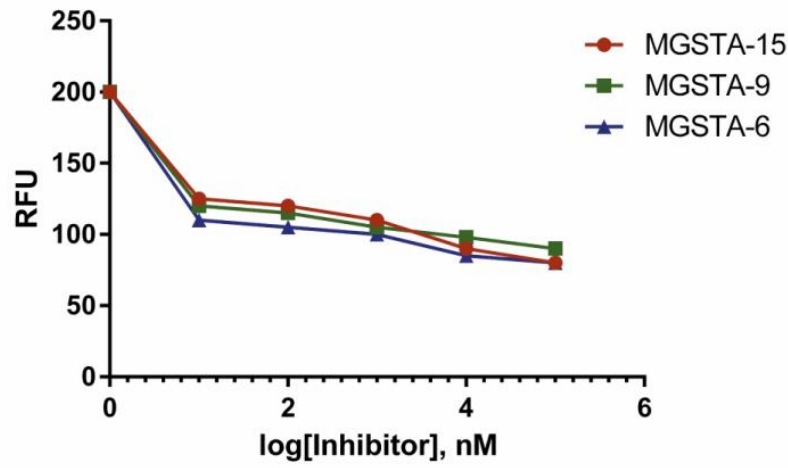

b)
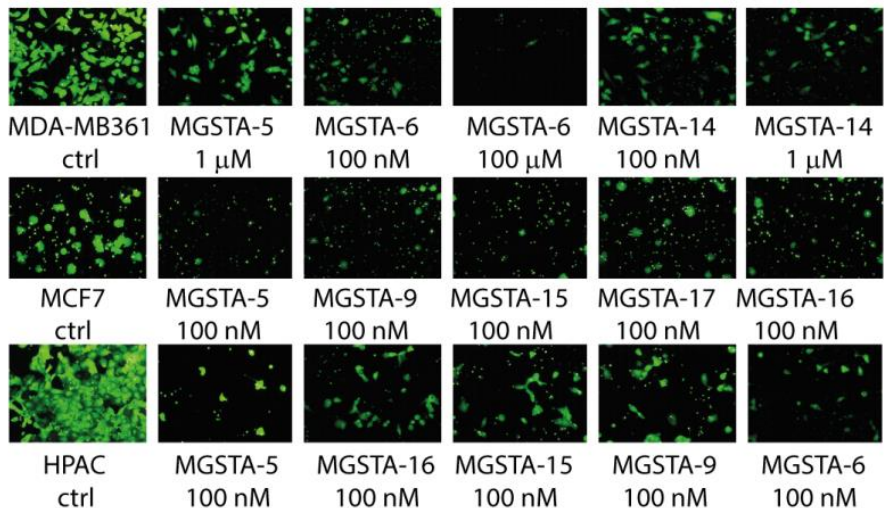

MGSTA-6

MGSTA-14

MGSTA-14
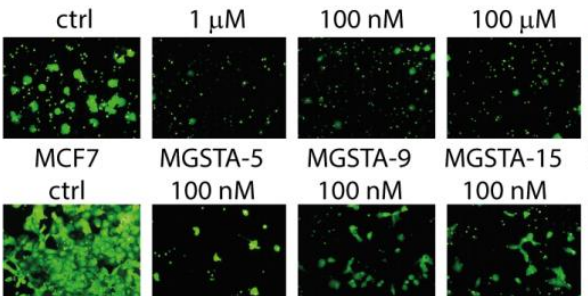

$100 \mathrm{nM}$

$1 \mu \mathrm{M}$
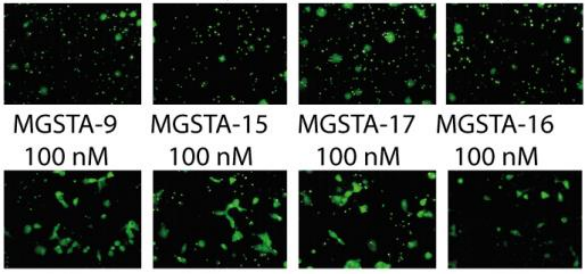

MGSTA-15 MGSTA-17 MGSTA-16

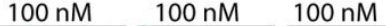

ctrl
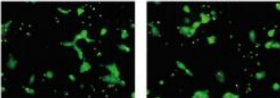

MGSTA-9 $100 \mathrm{nM}$

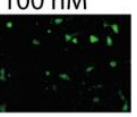

MGSTA-6 $100 \mathrm{nM}$

Figure 3. The effect of selected migrastatin analogues on human breast (MCF7, MDA-MB361) and pancreatic (HPAC) cancer cell lines. a) Quantification of migration of examined cell lines is presented as Relative Fluorescent Units (RFU). The treatment of cancer cells with selected migrastatin analogues at different concentrations, decreased cell migration through the membrane; $b$ ) Micrograph of the migrated MCF7, MDA-MB361 and HPAC cells taken with

Olympus microscopy BX60 at 4x magnification.

trans-well assays. Firstly, in order to eliminate the possibility that any decrease of migration was caused by an inhibition of cell proliferation or toxicity, rather than an interaction with the cell motility machinery, the effect of newly synthesized migrastatin-core analogues on three breast (MCF7, MCF7-Dox, MDA-MB361) and one pancreatic cancer (HPAC) cell lines were evaluated using the MTT assay. The newly synthesized analogues did not cause any toxicity or arrest of proliferation at low-invasive MCF7 ${ }^{[36]}$ and doxorubicin resistant MCF7-Dox breast cancer cells, with average scratch closure of $14.6 \%$ and $14.9 \%$ respectively. Interestingly, treatment of MDA-MB361 breast cancer cells with migrastatin analogues resulted in the inhibition of cell migration with an average scratch closure of 42.0\%. MDA-MB361 are known to have poor cell-cell adhesion. ${ }^{[36]}$ As a result, some migrastatin analogues were tested on the MDA-MB-231 cell line, that display a more invasive 
phenotype, ${ }^{[36]}$ and with this in vitro model, the average scratch closure was $63.3 \%$. When the migrastatin analogues where tested on the pancreatic cancer cell line, HPAC, we noted an average of scratch closure of $33.5 \%$ (see supporting information).

Next a selected number of the compounds tumour cell migration inhibitory activity was evaluated using the Boyden chamber assay as this is considered a superior model with which to conduct cell migration studies.[1] Eight of the compounds were selected based on considering macrocycle ring size and other structural features: compounds MGSTA-13 and MGSTA-14 were selected because of their relationship to the isomigrastatin macrocyclic core; MGSTA-9 contains an extra carbon in the macrocyclic ring compared to migrastatin; MGSTA- 6 possesses an $\alpha, \beta$-unsaturated carbonyl group that is present in migrastatin; MGSTA-15 is the direct analogue of MGSTA-4 with a methyl group instead of a methoxy in the 9 position; MGSTA-16 and $\mathbf{1 7}$ are the glucuronides and MGSTA-5 (Danishesky's macroketone), was selected for use as the internal control. As shown in Figure 2 and 3, the selected compounds, inhibit cell migration in the less invasive MCF7 cells in the nanomolar range. The only exception was MGSTA-6 which inhibited cell migration with considerably lower potency $\left(\mathrm{IC}_{50}>1 \mu \mathrm{M}\right)$ when compared with the macroketone MGSTA-5 $\left(\mathrm{IC}_{50}=13 \mathrm{nM}\right)$. The glucuronides were found to be less potent than the macroketone against this cell type with the $\beta$ glucuronide more potent than its $\alpha$-anomer. MGSTA-5,6 and 14 were tested using the more invasive MDA-MB361 cell line. Interestingly, MGSTA-6 $\left(\mathrm{IC}_{50}=410 \mathrm{nM}\right)$ was 2.4 fold more potent than MGSTA-5 $\left(\mathrm{IC}_{50}=974 \mathrm{nM}\right)$ in this particular cell line, contrasting with the result for the MCF7 cells. In addition, the isomigrastatin-core analogue MGSTA-14 strongly inhibited cell migration of MDA-MB361 cells $\left(\mathrm{IC}_{50}=301 \mathrm{nM}\right)$. MGSTA$5,6,9,15,16$ and 17 all strongly inhibited cell migration in HPAC cells, however, the curve dose response was very wide and the $\mathrm{IC}_{50}$ could not be extrapolated.

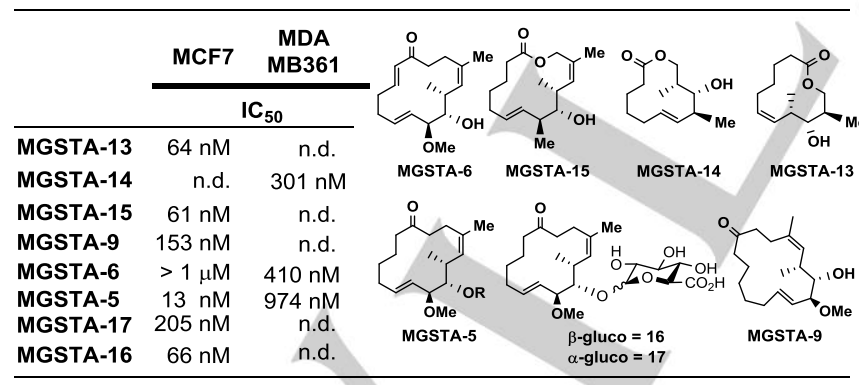

Figure 3. The effect of selected migrastatin analogues on human breast cancer cell lines MCF7 and MDA-MB36 assessed with Boyden chamber assay.

Thus, MGSTA-6 showed good cell migration inhibition in highly metastatic MDA-MB361 but not in less invasive MCF7 cells. This apparent paradox could be related with cytoskeleton proteins targeted by migrastatin analogues $[9,19]$ and with differents molecular changes occurring during the complex event of metastasis in invasive and non invasive cells. In a previous paper we showed that MGSTA-6 inhibited the formation and elongation of filopodia by interfering with fascin1-dependent cross-linking of actin filaments and subsequently leads to inhibition of stress fibres formation. ${ }^{[9]}$ Importance of these cytoskeleton rearangements in cancer invasion indicates a correlation between high fascin expression and poor prognosis in human carcinomas. ${ }^{[37]}$ Stress fibre formation is the last and crucial step of complex changes occuring in cytoskeleton of invasive cancer cell before its movement and it could tentatively explain the more pronounced biological activity of MGSTA-6 in MDA-MB361 cells (figure 2).

\section{In vitro pharmacological profile of MGSTA-6}

The pharmacological profile of a biologically active small molecule can be classified into primary (interaction with the intendent target) and secondary (interactions with differents targets). Interaction with secondary targets can lead to adverse drug reaction (ADRs). From the drug discovery point of view, it is extremely important to identify the potential side effects as early as possible. Recently, ${ }^{[38]}$ it has been suggested that drug candidates should be screened against a variety of targets (receptors, ion channels, enzymes and transporters). Compounds that interact with several of the above mentioned targets, are more prone to induce ADRs. Unsaturated macroketone MGSTA-6 strongly inhibits cell migration in MDAMB361 and HPAC cells (see above) and was earlier shown to interfere with the fascin1-dependent cross-linking of actin filaments leading to inhibition of stress fibers formation in canine mammary cancer cells. ${ }^{[9]}$ This agent was therefore selected from the panel of agents for screening against 55 targets (receptors, ion channels and transporters) known to be linked to ADRs. At the concentration of $10 \mu \mathrm{M}$, MGSTA- 6 only showed weak inhibition of two targets: adenosine receptor $A_{2 A}(27 \%)$ and prostanoid EP4 receptor (39\%). It has been suggested ${ }^{[38]}$ that compounds with a promiscuity index (percentage of targets giving more than $50 \%$ inhibition at $10 \mu \mathrm{M}$ in a set of at least 50 targets) of more than $20 \%$ should be considered promiscuous and this has been linked to market withdrawal and clinical trial failure. Unsaturated macroketone MGSTA-6, with a promiscuity index between $0-5 \%$, is a possible candidate as a tumour cell migration inhibitor with potentially low side effects. However, the pharmacological panel in this study does not include enzymes and further investigations would be necessary in order to confirm the selectivity of MGSTA-6 (Table S1)

\section{Conclusions}

The stereoselective synthesis of intermediates based on Brown allylation and alkoxyallylation has enabled the preparation of a series of migrastatin and isomigrastatin analogues. Chelation induced anomerisation is compatible with the various functionality found in the migrastatin macroketone skeleton and could be exploited to give macroketone glycosides for biological study. Compounds showed inhibitory activity when tested against breast and pancreatic cancer cell lines (MCF-7, MCF7Dox, MDA-MB631, MDA-MB261, HPAC) using the wound healing assay and Boyden chamber assay (nM range). One inhibitor (MGSTA-6) has low activity against a variety of receptors, ion channels and transporters, which indicates that it, 
and possibly other migrastatin analogues, may have potential to inhibit tumour metastasis without adverse drug reactions.

\section{Experimental Section}

General: NMR spectra were recorded on a $500 \mathrm{MHz}$ spectrometer at 30 ${ }^{\circ} \mathrm{C}$. Chemical shifts are reported relative to internal $\mathrm{Me}_{4} \mathrm{Si}_{\text {inCDCl }}(\delta=0.0$ ppm) for ${ }^{1} \mathrm{H}$ and $\mathrm{CDCl}_{3}(\delta=77.16 \mathrm{ppm})$ for ${ }^{13} \mathrm{C}$ at $30{ }^{\circ} \mathrm{C}$, unless otherwise stated. ${ }^{13} \mathrm{C}$ signals were assigned with the aid of HSQC. Coupling constants are reported in Hertz. High-resolution mass spectra were measured by using an LC time-of-flight mass spectrometer and were measured in positive and/or negative mode as indicated. TLC was performed on aluminium sheets pre-coated with Silica Gel 60 (HF254, Merck Millipore) and spots were visualised by charring with vanillin solutions. Chromatography was carried out by using silica gel $60(0.040$ $0.630 \mathrm{~mm}$, E. Merck). Dichloromethane, tetrahydrofuran, $\mathrm{MeOH}$ and toluene were used as obtained from a PureSolv solvent purification system. Petroleum ether is the fraction with b.p. $=40-60^{\circ} \mathrm{C}$.

General procedure for TBS deprotection. To a stirred solution of TBS protected macrocycle in THF (24 mM), HF•pyridine 70\% (250 eq) was added at RT. The resulting solution was stirred at RT for $18 \mathrm{~h}$. After the careful addition of MeOTMS (350 eq) the mixture was stirred for an additional $30 \mathrm{~min}$ and then the solvent was removed under reduced pressure and the residue was purified by flash chromatography (FC).

\section{(6E,8S,9S,10R,11Z)-9-hydroxy-8-methoxy-10,12-}

dimethyloxacyclotrideca-6,11-dien-2-one (MGSTA-1). Purification by FC (PE/EtOAc 10:1) afforded MGSTA-1 (15.1 mg, 61\%) as a white solid; $[\alpha]_{D}-13.0^{\circ}\left(\mathrm{c} 0.03, \mathrm{CHCl}_{3}\right) ;{ }^{1} \mathrm{H} \mathrm{NMR}\left(\mathrm{CDCl}_{3}, 500 \mathrm{MHz}\right): \delta 5.65-5.61(\mathrm{~m}$, $1 \mathrm{H}, \mathrm{H}-11$ ) $5.62-5.57$ (dd, $1 \mathrm{H}, J_{6,7 \text { trans }}=15.5, J_{5,6}=7.5 \mathrm{~Hz}, \mathrm{H}-6$ ), 5.26 (ddt, $\left.1 \mathrm{H}, J_{7,8}=6.2, J=1.4 \mathrm{~Hz}, \mathrm{H}-7\right), 5.13\left(\mathrm{dd}, 1 \mathrm{H}, J_{13,13^{\prime}}=12.1, J_{M e, 13}=1.2 \mathrm{~Hz}\right.$, $\mathrm{H}-13), 3.82\left(\mathrm{~d}, 1 \mathrm{H}, \mathrm{H}-13^{\prime}\right), 3.41-3.34(\mathrm{~m}, 1 \mathrm{H}, \mathrm{H}-8), 3.31-3.27(\mathrm{~m}, 4 \mathrm{H}$, $\left.\mathrm{OCH}_{3}, \mathrm{H}-9\right), 2.42-2.28\left(\mathrm{~m}, 3 \mathrm{H}, \mathrm{CH}_{2}, \mathrm{H}-10\right), 2.27-2.12\left(\mathrm{~m}, 2 \mathrm{H}, \mathrm{CH}_{2}\right)$, 2.05-1.94 (m, $\left.1 \mathrm{H}, \mathrm{CH}_{2}\right), 1.82\left(\mathrm{~d}, 3 \mathrm{H}, \mathrm{CH}_{3}\right.$ at $\left.\mathrm{C}-12\right), 1.77-1.68(\mathrm{~m}, 1 \mathrm{H}$, $\left.\mathrm{CH}_{2}\right), 0.95\left(\mathrm{~d}, 3 \mathrm{H}, \mathrm{J}_{10,10 \mathrm{Me}}=6.8 \mathrm{~Hz}, \mathrm{CH}_{3}\right.$ at $\left.\mathrm{C}-10\right) ;{ }^{13} \mathrm{C} \mathrm{NMR}\left(\mathrm{CDCl}_{3}, 125\right.$ $\mathrm{MHz}): \delta 173.4$ (C-2), $136.4(C-11), 132.9(C-6), 129.3(C-7), 128.5(C-12)$ $82.7(C-8), 77.6(C-9), 63.3(C-13), 56.8\left(\mathrm{OCH}_{3}\right), 32.9(C-10), 32.0\left(\mathrm{CH}_{2}\right)$, $31.7\left(\mathrm{CH}_{2}\right), 24.0\left(\mathrm{CH}_{3}\right.$ at $\left.\mathrm{C}-12\right), 21.8\left(\mathrm{CH}_{2}\right), 13.0\left(\mathrm{CH}_{3}\right.$ at $\left.\mathrm{C}-10\right)$; HRMSESI: calcd for $\mathrm{C}_{15} \mathrm{H}_{24} \mathrm{O}_{4} \mathrm{Na}$ : 291.1572; Found: 291.1584 .

(4Z,6R,7S,8S,9E)-7-hydroxy-8-methoxy-4,6-dimethylcyclotrideca-4,9dienone (MGSTA-2). Purification by FC (PE/EtOAc 10:1) afforded MGSTA-2 (11.8 mg, 84\%) as a yellow syrup; $[\alpha]_{D} 87.4$ (c 1.64, $\left.\mathrm{CHCl}_{3}\right) ;{ }^{1} \mathrm{H}$ $\operatorname{NMR}\left(\mathrm{CDCl}_{3}, 500 \mathrm{MHz}\right): \delta 5.62\left(\mathrm{ddd}, 1 \mathrm{H}, J_{9,10 \text { trans }}=15.0, \mathrm{~J}_{10,11}=8.5\right.$, $\left.J_{10,11^{\prime}}=5.9 \mathrm{~Hz}, \mathrm{H}-10\right), 5.30\left(\mathrm{~d}, 1 \mathrm{H}, J_{5,6}=10 \mathrm{~Hz}, \mathrm{H}-5\right), 5.22$ (ddt, $1 \mathrm{H}, J_{8,9}=$ 7.6, $J=1.3 \mathrm{~Hz}, \mathrm{H}-9), 3.37-3.34(\mathrm{~m}, 1 \mathrm{H}, \mathrm{H}-8), 3.31-3.29(\mathrm{~m}, 4 \mathrm{H}, \mathrm{H}-7$ and $\left.\mathrm{OCH}_{3}\right), 2.82(\mathrm{~s}, 1 \mathrm{H}, \mathrm{OH}), 2.64-2.59\left(\mathrm{~m}, 1 \mathrm{H}, \mathrm{CH}_{2}\right), 2.51-2.45(\mathrm{~m}, 2 \mathrm{H}$, $\left.\mathrm{CH}_{2}\right), 2.43-2.25\left(\mathrm{~m}, 4 \mathrm{H}, \mathrm{H}-6, \mathrm{CH}_{2}\right), 2.10-2.03\left(\mathrm{~m}, 1 \mathrm{H}, \mathrm{CH}_{2}\right), 1.91-1.81$ $\left(\mathrm{m}, 2 \mathrm{H}, \mathrm{CH}_{2}\right), 1.76-1.70\left(\mathrm{~m}, 1 \mathrm{H}, \mathrm{CH}_{2}\right), 1.70\left(\mathrm{~d}, 3 \mathrm{H}, \mathrm{J}=1.3 \mathrm{~Hz}, \mathrm{CH}_{3}\right.$ at $\mathrm{C}$ 4), $0.95\left(\mathrm{~d}, 3 \mathrm{H}, \mathrm{J}_{6, \mathrm{Me}}=6.9 \mathrm{~Hz}, \mathrm{CH}_{3}\right.$ at C-6); ${ }^{13} \mathrm{C} \mathrm{NMR}\left(125 \mathrm{MHz}, \mathrm{CDCl}_{3}\right) \delta$ 210.7 (C-1), 135.7 (C-10), 133.9 (Cq), 130.7 (C-5), 129.5 (C-9), 83.9 (C8), 77.8 (C-7), $56.4\left(\mathrm{OCH}_{3}\right), 42.5\left(\mathrm{CH}_{2}\right), 40.2\left(\mathrm{CH}_{2}\right), 32.9(\mathrm{C}-6), 31.9$ $\left(\mathrm{CH}_{2}\right), 26.3\left(\mathrm{CH}_{2}\right), 23.6\left(\mathrm{CH}_{3}\right), 21.5\left(\mathrm{CH}_{2}\right), 13.9\left(\mathrm{CH}_{3}\right)$. HRMS-ESI: calcd for $\mathrm{C}_{16} \mathrm{H}_{26} \mathrm{O}_{3} \mathrm{Na}$ : 289.1780; Found: 289.1772.

\section{(6E,8S,9S,10R,11Z)-9-hydroxy-8-methoxy-10,12-}

dimethylthiacyclotrideca-6,11-dien-2-one (MGSTA-3). Purification by FC (PE/EtOAc 15:1) afforded MGSTA-3 (5.0 mg, 85\%) as a yellow syrup; [a] $]_{D} 1.6$ (c 0.46, $\mathrm{CHCl}_{3}$ ); ${ }^{1} \mathrm{H} \mathrm{NMR}\left(\mathrm{CDCl}_{3}, 500 \mathrm{MHz}\right.$ ): $\delta 5.65-5.48$ ( $\mathrm{m}, 2 \mathrm{H}, \mathrm{H}-6,10$ ), 5.15-5.05 (dd, $1 \mathrm{H}, J_{6, \text { Arans }}=15.4, J_{7,9}=7.7 \mathrm{~Hz}, \mathrm{H}-7$ ), $4.21(\mathrm{~d}, 1 \mathrm{H}, J=13.4, \mathrm{H}-13), 3.33-3.27(\mathrm{~m}, 2 \mathrm{H}, \mathrm{H}-7,8), 3.26$ (s, $3 \mathrm{H}$,
$\mathrm{OCH}_{3}$ ), 2.84 (s, 1H, OH), 2.78 (d, 1H, H-13'), 2.66 (ddd, 1H, $J=16.7,7.0$, $2.0 \mathrm{~Hz}, \mathrm{H}-3), 2.57-2.51\left(\mathrm{~m}, 1 \mathrm{H}, \mathrm{H}-3^{\prime}\right), 2.51-2.42(\mathrm{~m}, 1 \mathrm{H}, \mathrm{H}-5), 2.22(\mathrm{~m}$, $1 \mathrm{H}, \mathrm{H}-4), 2.12(\mathrm{~m}, 1 \mathrm{H}, \mathrm{H}-10), 2.01-1.92\left(\mathrm{~m}, 1 \mathrm{H}, \mathrm{H}-5^{\prime}\right), 1.76-1.74(\mathrm{~s}, 3 \mathrm{H}$, Me at C-12), 1.69-1.62 (m, 1H, H-4'), $0.97\left(\mathrm{~d}, 3 \mathrm{H}, \mathrm{J}_{10, \mathrm{Me}}=6.8, \mathrm{~Hz}\right.$, Me at C-10). ${ }^{13} \mathrm{C}$ NMR $\left(125 \mathrm{MHz}, \mathrm{CDCl}_{3}\right)$ : $\delta 198.0$ (C-2), 136.8 (C-6), 133.9 (C10), 130.1 (C-11), 128.8 (C-7), 83.1 (C-8 or C-9), 75.0 (C-8 or C-9), 56.3 $\left(\mathrm{OCH}_{3}\right), 43.7$ (C-3), 34.3 (C-5), 32.5 (C-10), $28.9(\mathrm{C}-13), 25.3\left(\mathrm{CH}_{3}\right.$ at C12), 22.7 (C-4), $12.6\left(\mathrm{CH}_{3}\right.$ at $\left.\mathrm{C}-10\right)$. HRMS-ESI: calcd for $\mathrm{C}_{15} \mathrm{H}_{23} \mathrm{O}_{3} \mathrm{~S}$ : 283.1368; Found: 283.1375.

(2E,6E,8S,9S,10R,11Z)-9-((tert-butyldimethylsilyl)oxy)-8-methoxy10,12-dimethylcyclotetradeca-2,6,11-trien-1-one (13).

To stirred $12 \mathrm{~b}(26.7 \mathrm{mg} ; 0.068 \mathrm{mmol})$ in THF $(0.5 \mathrm{~mL})$ at $0^{\circ} \mathrm{C}, \mathrm{TMSCl}(26$ $\mu \mathrm{L} ; 0.203 \mathrm{mmol}$ ) and LHMDS (203 $\mu \mathrm{L} ; 0.203 \mathrm{mmol}, 1 \mathrm{M}$ in THF) were added dropwise. The resulting solution was stirred for $2 \mathrm{~h}$ at $0^{\circ} \mathrm{C}$, quenched with $\mathrm{NH}_{4} \mathrm{Cl}$ and extracted with EtOAc. The organic layers were dried over $\mathrm{Na}_{2} \mathrm{SO}_{4}$, filtered and the solvent was removed under reduced pressure. The residue was dissolved in $\mathrm{CH}_{3} \mathrm{CN}(0.5 \mathrm{~mL})$ and $\mathrm{Pd}(\mathrm{OAc})_{2}$ (18 mg; $0.082 \mathrm{mmol}$ ) was added. The mixture was stirred for $3 \mathrm{~h}$ and then diluted with $\mathrm{NaHCO}$ and extracted with $\mathrm{CH}_{2} \mathrm{Cl}_{2}$. The organic layers were dried over $\mathrm{Na}_{2} \mathrm{SO}_{4}$, filtered and the solvent was removed under reduced pressure. Purification by FC (PE/EtOAc 20:1) afforded 14 (17 mg: 64\%) as a yellow syrup; $[\alpha]_{D} 42.9^{\circ}$ (c 1.2, $\left.\mathrm{CHCl}_{3}\right) ;{ }^{1} \mathrm{H} \mathrm{NMR}\left(\mathrm{CDCl}_{3}, 500 \mathrm{MHz}\right): \delta$ $6.74\left(\mathrm{dt}, 1 \mathrm{H}, \mathrm{J}_{2,3}=16.2, J_{3,4}=7.0 \mathrm{~Hz}, \mathrm{H}-3\right), 5.93(\mathrm{~d}, 1 \mathrm{H} \mathrm{H}-2), 5.64$ (ddd, $\left.1 \mathrm{H}, J_{6,7}=15.4, J=8.9, J=4.7 \mathrm{~Hz}, \mathrm{H}-6\right), 5.37-5.14(\mathrm{~m}, 2 \mathrm{H}, \mathrm{H}-7,11)$, 3.45-3.27 (m, 2H, H-8,9), $3.21\left(\mathrm{~s}, 3 \mathrm{H}, \mathrm{OCH}_{3}\right), 2.70-2.31(\mathrm{~m}, 7 \mathrm{H}, \mathrm{H}-$ 10, $\left.\mathrm{CH}_{2}\right), 2.31-2.20\left(\mathrm{~m}, 1 \mathrm{H}, \mathrm{CH}_{2}\right), 2.05\left(\mathrm{~m}, 1 \mathrm{H}, \mathrm{CH}_{2}\right), 1.69(\mathrm{~d}, 3 \mathrm{H}, J=1.5$ $\mathrm{Hz}, \mathrm{Me}$ at C-12), $0.90\left(\mathrm{~s}, 9 \mathrm{H}, \mathrm{C}\left(\mathrm{CH}_{3}\right)_{3}\right), 0.87(\mathrm{~d}, 3 \mathrm{H}, J=6.6 \mathrm{~Hz}$, Me at C10), $0.04\left(\mathrm{~s}, 3 \mathrm{H}, \mathrm{SiCH}_{3}\right), 0.00\left(\mathrm{~s}, 3 \mathrm{H}, \mathrm{SiCH}_{3}\right) ;{ }^{13} \mathrm{C} \mathrm{NMR}(125 \mathrm{MHz}$, $\mathrm{CDCl}_{3}$ ): $\delta 201.5$ (C-1), 148.2 (C-3), 132.8 (C-6), 132.0, 132.0, 131.7, 131.4, 85.2 (C-8 or C-9), 79.0 (C-8 or C-9), $56.4\left(\mathrm{OCH}_{3}\right), 38.4\left(\mathrm{CH}_{2}\right)$, $34.5(\mathrm{C}-10), 32.4\left(\mathrm{CH}_{2}\right), 31.6\left(\mathrm{CH}_{2}\right), 30.7\left(\mathrm{CH}_{2}\right), 26.3\left(\mathrm{C}\left(\mathrm{CH}_{3}\right)_{3}\right), 23.0(\mathrm{Me}$ at $\mathrm{C}-12), 18.8\left(\mathrm{C}_{\left.\left(\mathrm{CH}_{3}\right)_{3}\right),}, 12.7(\mathrm{Me}\right.$ at $\mathrm{C}-10),-3.7\left(\mathrm{SiCH}_{3}\right),-4.9\left(\mathrm{SiCH}_{3}\right)$; HRMS-ESI: calcd for $\mathrm{C}_{23} \mathrm{H}_{39} \mathrm{O}_{3} \mathrm{Si}$ : 391.2668; Found: 391.2678 .

\section{(2E,6E,8S,9S,10R,11Z)-9-hydroxy-8-methoxy-10,12-}

dimethylcyclotetradeca-2,6,11-trienone (MGSTA-6). Purification by FC (PE/EtOAc 5:1) afforded MGSTA-6 $(7.6 \mathrm{mg}, 90 \%)$ as a yellow syrup; [a] $92.2^{\circ}$ (c $\left.0.6, \mathrm{CHCl}_{3}\right) ;{ }^{1} \mathrm{H} \mathrm{NMR}\left(\mathrm{CDCl}_{3}, 500 \mathrm{MHz}\right.$ ): $\delta 6.73$ (dt, $1 \mathrm{H}, J_{2,3}=16.4$, $\left.J_{3,4}=7.1 \mathrm{~Hz}, \mathrm{H}-3\right), 5.93(\mathrm{~d}, 1 \mathrm{H}, \mathrm{H}-2), 5.69$ (ddd, $1 \mathrm{H}, J_{6,7}=15.4, J=9.4, J$ $=4.4 \mathrm{~Hz}, \mathrm{H}-6), 5.37$ (d, $\left.1 \mathrm{H}, J_{10,11}=9.9 \mathrm{~Hz}, \mathrm{H}-11\right), 5.24$ (ddd, $1 \mathrm{H}, J_{7,8}=$ 8.4, $J=1.4 \mathrm{~Hz}, \mathrm{H}-7$ ), 3.44 (appt, $1 \mathrm{H}, J_{7,8}=J_{8,9}=8.9 \mathrm{~Hz}, \mathrm{H}-8$ ), 3.34 (dd, $1 \mathrm{H}, J=1.3 \mathrm{~Hz}, \mathrm{H}-9), 3.31\left(\mathrm{~s}, 3 \mathrm{H}, \mathrm{OCH}_{3}\right), 2.70(\mathrm{~s}, 1 \mathrm{H}, \mathrm{OH}), 2.64(\mathrm{~m}, 1 \mathrm{H}$, $\mathrm{CH}_{2}$ ), 2.57-2.46 (m, 4H, H-10, $\left.\mathrm{CH}_{2}\right), 2.42-2.22\left(\mathrm{~m}, 3 \mathrm{H}, \mathrm{CH}_{2}\right), 2.14(\mathrm{~m}$, $\left.1 \mathrm{H}, \mathrm{CH}_{2}\right), 1.72(\mathrm{~d}, 3 \mathrm{H}, J=1.4 \mathrm{~Hz}, \mathrm{Me}$ at $\mathrm{C}-12), 0.92(\mathrm{~d}, 3 \mathrm{H}, J=6.8 \mathrm{~Hz}$, Me at $\mathrm{C}-10) ;{ }^{13} \mathrm{C} \mathrm{NMR}\left(125 \mathrm{MHz}, \mathrm{CDCl}_{3}\right): \delta 201.3$ (C-1), 147.8 (C-3), 134.9 (C-6), 132.9 (C-12), 131.7 (C-2), 130.9 (C-11), 130.5 (C-7), 84.1 (C-8), $77.2(\mathrm{C}-9), 56.6\left(\mathrm{OCH}_{3}\right), 38.4\left(\mathrm{CH}_{2}\right), 32.7(\mathrm{C}-10), 32.3\left(\mathrm{CH}_{2}\right), 31.3$ $\left(\mathrm{CH}_{2}\right), 30.6\left(\mathrm{CH}_{2}\right), 22.9$ (Me at C-12), 12.6 (Me at C-10). HRMS-ESI: calcd for $\mathrm{C}_{17} \mathrm{H}_{25} \mathrm{O}_{3}$ : 277.1804; Found: 277.1801 .

\section{(7E,9S,10S,11R,12Z)-10-hydroxy-9-methoxy-11,13-}

dimethylthiacyclotetradeca-7,12-dien-2-one (MGSTA-7). Purification by FC (hexane/EtOAc 15:1) afforded MGSTA-7 (12.8 mg, 63\%) as a yellow syrup; $[\alpha]_{D} 93.2$ (c $\left.0.07, \mathrm{CHCl}_{3}\right) ;{ }^{1} \mathrm{H} \mathrm{NMR}\left(\mathrm{CDCl}_{3}, 500 \mathrm{MHz}\right.$ ): $\delta$ 5.80-5.70 (m, $1 \mathrm{H}, \mathrm{H}-7), 5.58\left(\mathrm{~d}, 1 \mathrm{H}, J_{11,12}=9.6 \mathrm{~Hz}, \mathrm{H}-12\right), 5.28-5.20$ (ddt, $\left.1 \mathrm{H}, J_{7,8}=15.8, J_{8,9}=7.3, J=1.4 \mathrm{~Hz}, \mathrm{H}-8\right), 3.72\left(\mathrm{~d}, 1 \mathrm{H}, J_{14,14^{\prime}}=12.4\right.$ $\mathrm{Hz}, \mathrm{H}-14), 3.43\left(\mathrm{dd}, 1 \mathrm{H}, J_{9,10}=9.0 \mathrm{~Hz}, \mathrm{H}-9\right), 3.35\left(\mathrm{dd}, 1 \mathrm{H}, \mathrm{J}_{10, \mathrm{OH}}=1.6 \mathrm{~Hz}\right.$, $\mathrm{H}-10), 3.30$ (s, 3H, OMe), 3.18 (d, 1H, H-14'), 2.80 (bs, 1H, OH), 2.61 (m, $1 \mathrm{H}), 2.49-2.37\left(\mathrm{~m}, 2 \mathrm{H}, \mathrm{H}-11\right.$ and $\left.\mathrm{CH}_{2}\right), 2.22(\mathrm{~m}, 1 \mathrm{H}), 2.02(\mathrm{~m}, 1 \mathrm{H}), 1.77$ (d, $3 \mathrm{H}, J=1.4 \mathrm{~Hz}, M e$ at $\mathrm{C}-13), 1.75-1.59(\mathrm{~m}, 3 \mathrm{H}), 1.45-1.35(\mathrm{~m}, 1 \mathrm{H})$, 
$0.95\left(\mathrm{~d}, 3 \mathrm{H}, J=6.9 \mathrm{~Hz}, \mathrm{Me}\right.$ at C-11); ${ }^{13} \mathrm{C} \mathrm{NMR}\left(\mathrm{CDCl}_{3}, 125 \mathrm{MHz}\right): \delta 200.9$ (C-2), 135.0 (C-7), 134.2 (C-12), 128.4 (C-13), 127.8 (C-8), 83.8 (C-9), 76.6 (C-10), $56.6(\mathrm{OMe}), 43.5\left(\mathrm{CH}_{2}\right), 32.9(\mathrm{C}-11), 31.1(\mathrm{C}-14), 29.6\left(\mathrm{CH}_{2}\right)$ $27.4\left(\mathrm{CH}_{2}\right), 25.6\left(\mathrm{CH}_{2}\right), 25.1$ (Me at C-13), 12.8 (Me at C-11); HRMS-ESI: calcd for $\mathrm{C}_{16} \mathrm{H}_{26} \mathrm{O}_{3} \mathrm{NaS}$ : 321.1500; Found: 321.1496.

\section{(8E,10S,11S,12R,13Z)-11-hydroxy-10-methoxy-12,14-}

dimethyloxacyclopentadeca-8,13-dien-2-one (MGSTA-8). Purification by FC (PE/EtOAc 10:1 $\rightarrow 5: 1)$ afforded MGSTA-8 (28.7 mg, 54\%) as a white syrup; $[\alpha]_{D} 72^{\circ}$ (c 1.7, $\mathrm{CHCl}_{3}$ ); ${ }^{1} \mathrm{H} \mathrm{NMR}\left(\mathrm{CDCl}_{3}, 500 \mathrm{MHz}\right.$ ): $\delta 5.79$ (dq, $1 \mathrm{H}, J_{12,13}=9.4, J_{13, M e}=1.6 \mathrm{~Hz}, \mathrm{H}-13$ ), 5.64 (ddd, $1 \mathrm{H}, J_{8,9}=15.3, J_{8,7}$ $\left.=8.9, J_{8,7}=5.2 \mathrm{~Hz}, \mathrm{H}-8\right), 5.16\left(\mathrm{dd}, 1 \mathrm{H}, J_{9,10}=8.0 \mathrm{~Hz}, \mathrm{H}-9\right), 4.52(\mathrm{~d}, 1 \mathrm{H}$, $\left.J_{15 a, 15 b}=11.8 \mathrm{~Hz}, \mathrm{H}-15 \mathrm{a}\right), 4.27(\mathrm{~d}, 1 \mathrm{H}, \mathrm{H}-15 \mathrm{~b}), 3.46-3.34(\mathrm{~m}, 2 \mathrm{H}, \mathrm{H}-10$, $\mathrm{H}-12$ ), 3.29 (s, 3H, OMe), 2.82 (t, 1H, JoH,12=1.3 Hz, OH), 2.51 (q, $1 \mathrm{H}, J$ $=7.4 \mathrm{~Hz}), 2.39-2.26(\mathrm{~m}, 2 \mathrm{H}), 2.28-2.18(\mathrm{~m}, 1 \mathrm{H}, \mathrm{H}-7), 2.11-2.00(\mathrm{~m}$, $\left.1 \mathrm{H}, \mathrm{H}^{\prime} \mathrm{7}^{\prime}\right), 1.81$ (d, 3H, C-14Me), $1.74-1.55(\mathrm{~m}, 2 \mathrm{H}), 1.50-1.33(\mathrm{~m}, 2 \mathrm{H}$, $\left.\mathrm{H}-6,6^{\prime}\right), 1.30-1.10(\mathrm{~m}, 2 \mathrm{H}), 0.96$ (d, 3H, C-12Me); ${ }^{13} \mathrm{C} \mathrm{NMR}\left(\mathrm{CDCl}_{3}, 125\right.$ $\mathrm{MHz}$ ): $\delta 175.0$ (C-2), 136.7 (C-8), 136.3 (C-13), 128.2 (C-14), 128.0 (C9), 84.0 (C-11 or C-10), 76.0 (C-11 or C-10), 64.0 (C-15), 56.2 (OMe), $35.1\left(\mathrm{CH}_{2}\right), 32.9$ (C-12), 32.0 (C-7), $27.6\left(\mathrm{CH}_{2}\right), 27.4(\mathrm{C}-6), 25.8\left(\mathrm{CH}_{2}\right)$, $23.5(\mathrm{Me}), 13.2(\mathrm{Me})$. HRMS-ESI: calcd for $\mathrm{C}_{17} \mathrm{H}_{28} \mathrm{O}_{4} \mathrm{Na}$ : 319.1885; Found: 319.1882 .

(4Z,6R,7S,8S,9E)-7-hydroxy-8-methoxy-4,6-dimethylcyclopentadeca4,9-dienone (MGSTA-9). Purification by FC (PE/EtOAc 10:1) afforded MGSTA-9 (11.8 mg, 82\%) as a white syrup; [a] $]_{D} 87^{\circ}$ (c $0.9, \mathrm{CHCl}_{3}$ ); ${ }^{1} \mathrm{H}$ $\mathrm{NMR}\left(\mathrm{CDCl}_{3}, 500 \mathrm{MHz}\right): \delta 5.66$ (ddd, $\left.1 \mathrm{H}, J 14.7,8.8,5.2 \mathrm{~Hz}, \mathrm{H}-10\right), 5.41$ (d, $\left.1 \mathrm{H}, J_{5,6}=9.6 \mathrm{~Hz}, \mathrm{H}-5\right), 5.17$ (dd, $1 \mathrm{H}, J_{8,9}=7.3 \mathrm{~Hz}, \mathrm{H}-9$ ), 3.44-3.33 (m, $2 \mathrm{H}, \mathrm{H}-7,8), 3.28(\mathrm{~s}, 3 \mathrm{H}, \mathrm{OMe}), 2.78\left(\mathrm{~d}, 1 \mathrm{H}, \mathrm{J}_{7, \mathrm{OH}}=1.3 \mathrm{~Hz}, \mathrm{OH}\right), 2.51-$ $2.31(\mathrm{~m}, 5 \mathrm{H}), 2.29-2.17(\mathrm{~m}, 2 \mathrm{H}), 2.14-2.01(\mathrm{~m}, 2 \mathrm{H}), 1.73-1.56(\mathrm{~m}, 5 \mathrm{H})$, 1.52-1.34 (m, 2H), 1.29-1.08 (m, 2H), $0.93\left(\mathrm{~d}, 3 \mathrm{H}, J_{6, M e}=6.8 \mathrm{~Hz}\right.$, $\mathrm{C} 6 \mathrm{Me}) ;{ }^{13} \mathrm{C} \mathrm{NMR}\left(\mathrm{CDCl}_{3}, 125 \mathrm{MHz}\right): \delta 213.0$ (C-1), 136.5 (C-10), 133.4 (C-4), 129.8 (C-5), 128.1 (C-9), 84.2 (C-7 or C-8), 76.6 (C-7 or C-8), 56.3 (OMe), $43.1\left(\mathrm{CH}_{2}\right), 41.8\left(\mathrm{CH}_{2}\right), 32.7(\mathrm{C}-6), 31.8\left(\mathrm{CH}_{2}\right), 27.9\left(\mathrm{CH}_{2}\right), 27.8$ $\left(\mathrm{CH}_{2}\right), 26.4\left(\mathrm{CH}_{2}\right), 25.7\left(\mathrm{CH}_{2}\right), 23.4(\mathrm{Me}$ at $\mathrm{C}-4), 13.0$ (Me at $\left.\mathrm{C}-6\right)$. HRMS-ESI: calcd for $\mathrm{C}_{18} \mathrm{H}_{30} \mathrm{O}_{3} \mathrm{Na}$ : 317.2093; Found: 317.2087.

(2R,3R,4S)-2,4-dimethylhex-5-ene-1,3-diol (26). To stirred t-BuOK (1.63 g; $14.57 \mathrm{mmol})$ in THF $(4 \mathrm{~mL})$ at $-45^{\circ} \mathrm{C}$ n-butyllithium in heptane (9.1 mL, $14.57 \mathrm{mmol}, 1.6 \mathrm{M}$ ) was added. The mixture was cooled to $78^{\circ} \mathrm{C}$ and $\beta$-methoxydiisopinocampheylborane $(5.5 \mathrm{~g}, 17.4 \mathrm{mmol})$ in THF $\left(17 \mathrm{~mL}\right.$ ) was added via cannula over The mixture was stirred at $-78^{\circ} \mathrm{C}$ for an additional $1 \mathrm{~h}$ and boron trifluoride etherate $(2.4 \mathrm{~mL}, 19.45 \mathrm{mmol})$ was added dropwise at $-78^{\circ} \mathrm{C}$. Immediately, a solution of aldehyde $25(3.94 \mathrm{~g}$, $20.52 \mathrm{mmol})$ in THF $(7 \mathrm{~mL})$ was added, and the mixture was stirred at $78^{\circ} \mathrm{C}$ for $18 \mathrm{~h}$. Then aqueous $\mathrm{NaOH}(10.66 \mathrm{~mL} ; 32 \mathrm{mmol}, 3 \mathrm{M})$ was added followed by $\mathrm{H}_{2} \mathrm{O}_{2}(4.5 \mathrm{~mL}, 30 \%)$, and the biphasic mixture was allowed to warm to room temperature slowly and refluxed for $1 \mathrm{~h}$. The solution was diluted with $\mathrm{CH}_{2} \mathrm{Cl}_{2}$ and washed with water. Organic layer was separated, and then dried over $\mathrm{Na}_{2} \mathrm{SO}_{4}$ and the solvent was removed under reduced pressure. The residue was subjected to silica gel chromatography (PE: EtOAc, 1:6) affording a mixture of the title compound and pinenol during the work-up $(9.87 \mathrm{~g})$ which can be used directly in the next step. The mixture $(9.87 \mathrm{~g})$ was dissolved in dry methanol $(200 \mathrm{~mL})$ and $\mathrm{K}_{2} \mathrm{CO}_{3}$ $(2.32 \mathrm{~g})$ was added. After stirring at room temperature for $24 \mathrm{~h} \mathrm{AcOH}$ was added until the $\mathrm{pH}=7$. The solvent was removed under reduced pressure and the residue was purified by chromatography (PE: EtOAc $\left.1: 10 \rightarrow \mathrm{Et}_{2} \mathrm{O}\right)$ to afford $26(940 \mathrm{mg} ; 32 \%$ from 25$)$ as white crystal (needles); $\mathrm{Mp}=175-181^{\circ} \mathrm{C} ;{ }^{1} \mathrm{H} \mathrm{NMR}\left(\mathrm{CDCl}_{3}, 500 \mathrm{MHz}\right) \delta 5.62$ (ddd, $1 \mathrm{H}$, $\left.J_{5,6 \text { trans }}=17.1, J_{5,6 c i s}=10.3, J_{4,5}=8.7 \mathrm{~Hz}, \mathrm{H}-5\right), 5.08-5.04(\mathrm{~m}, 1 \mathrm{H}, \mathrm{H}-$ $6_{\text {trans }}$ ), 4.98 (dd, $\left.1 \mathrm{H}, J_{\text {gem }}=1.8 \mathrm{~Hz}, \mathrm{H}-6_{c i s}\right), 3.71\left(\mathrm{dd}, 1 \mathrm{H}, J_{1,1^{\prime}}=10.5, J_{1,2}=\right.$
$4.1 \mathrm{~Hz}, \mathrm{H}-1$ ), 3.66 (dd, $\left.1 \mathrm{H}, J_{1,2}^{\prime}=5.5 \mathrm{~Hz}, \mathrm{H}-1^{\prime}\right), 3.56\left(\mathrm{dd}, 1 \mathrm{H}, J_{3,4}=9.1\right.$, $J_{2,3}=2.4 \mathrm{~Hz}, \mathrm{H}-3$ ), 2.67 (bs, $2 \mathrm{H}, \mathrm{OH}$ ), $2.33-2.26$ (m, 1H, H-4), 1.82 (dddd, $\left.1 \mathrm{H}, J_{2, M e}=6.8 \mathrm{~Hz}, \mathrm{H}-2\right), 1.09\left(\mathrm{~d}, 3 \mathrm{H}, \mathrm{J}_{4, M e}=6.7 \mathrm{~Hz}, \mathrm{CH}_{3}\right.$ at $\left.\mathrm{C}-4\right)$, $0.93\left(\mathrm{~d}, 3 \mathrm{H}, \mathrm{CH}_{3}\right.$ at $\left.\mathrm{C}-2\right) ;{ }^{13} \mathrm{C} \mathrm{NMR}\left(\mathrm{CDCl}_{3}, 125 \mathrm{MHz}\right) \delta 141.0$ (C-5), 114.9 (C-6), 77.5 (C-3), 67.9 (C-1), 42.4 (C-4), 36.7 (C-2), $17.3\left(\mathrm{CH}_{3}\right.$ at C-4), $9.1\left(\mathrm{CH}_{3}\right.$ at C-2); HRMS-ESI: calcd for $\mathrm{C}_{8} \mathrm{H}_{15} \mathrm{O}_{2} \mathrm{Na}$ : 143.1072; Found: 143.1071

Ring-Closing Metathesis on MGSTA-10. To a stirred solution of MGSTA-10 (100 mg; $0.33 \mathrm{mmol}$ ), in degassed $\mathrm{PhCH}_{3}(650 \mathrm{~mL})$ the Grubbs II catalyst $(57 \mathrm{mg}, 0.067 \mathrm{mmol})$ was added via canula. The mixture was stirred at reflux for $60 \mathrm{~min}$. The $\mathrm{PhCH}_{3}$ was removed under reduced pressure. Purification of the residue by FC (EtOAc/Cy 1:30) afforded MGSTA-11 (25 mg, 31\%) and MGSTA-12 (23.1 mg; 33\%) as yellow syrups.

(9S,10R,11R,Z)-10-(methoxymethoxy)-9,11-dimethyloxacyclododec7-en-2-one (MGSTA-11). ${ }^{1} \mathrm{H}$ NMR $\left(\mathrm{CDCl}_{3}, 500 \mathrm{MHz}\right) \delta 5.48$ - 5.40 (m, $1 \mathrm{H}, \mathrm{H}-8$ ), 5.34 (td, $\left.1 \mathrm{H}, \mathrm{J}_{7,8}=10.6, \mathrm{~J}_{6,7}=5.0 \mathrm{~Hz}, \mathrm{H}-7\right), 4.67$ (d, 1H, J=6.6 $\mathrm{Hz}, \mathrm{OCH}_{2} \mathrm{O}$ ), $4.62\left(\mathrm{~d}, 1 \mathrm{H}, \mathrm{J}=6.6 \mathrm{~Hz}, \mathrm{OCH}_{2} \mathrm{O}\right), 4.38\left(\mathrm{dd}, 1 \mathrm{H}, \mathrm{J}_{12,12^{\prime}}=11.4\right.$, $\left.J_{12,11}=3.1 \mathrm{~Hz}, \mathrm{H}-12\right), 3.89\left(\mathrm{dd}, 1 \mathrm{H}, J_{11,12^{\prime}}=5.2 \mathrm{~Hz}, \mathrm{H}-12^{\prime}\right), 3.43-3.38(\mathrm{~m}$, $\left.4 \mathrm{H}, \mathrm{H}-10, \mathrm{OCH}_{3}\right), 2.71$ (dqd, $1 \mathrm{H}, \mathrm{J}_{8,9}=9.9, \mathrm{~J}_{9, M_{e}}=6.8, \mathrm{Jg}_{9,10}=2.9 \mathrm{~Hz}, \mathrm{H}-9$ ), 2.44 (ddd, $1 \mathrm{H}, J=12.7,8.5,3.9 \mathrm{~Hz}, \mathrm{CH}_{2}$ ), 2.33 (ddd, $1 \mathrm{H}, J=13.3,8.9$, $\left.3.7 \mathrm{~Hz}, \mathrm{CH}_{2}\right), 2.26-2.14\left(\mathrm{~m}, 1 \mathrm{H}, \mathrm{CH}_{2}\right), 2.14-2.02(\mathrm{~m}, 1 \mathrm{H}, \mathrm{H}-11), 1.91-$ $1.75\left(\mathrm{~m}, 2 \mathrm{H}, \mathrm{CH}_{2}\right.$ ), 1.64 (dddt, $\left.2 \mathrm{H}, \mathrm{J}=20.6,8.7,5.8,3.2 \mathrm{~Hz}, \mathrm{CH}_{2}\right), 1.42-$ $1.29\left(\mathrm{~m}, 1 \mathrm{H}, \mathrm{CH}_{2}\right), 1.11\left(\mathrm{~d}, 3 \mathrm{H}, J=7.3 \mathrm{~Hz}, \mathrm{CH}_{3}\right.$ at $\left.\mathrm{C}-11\right), 0.98(\mathrm{~d}, 3 \mathrm{H}, J=$

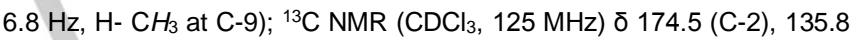
(C-8), 128.6 (C-7), $98.3\left(\mathrm{OCH}_{2} \mathrm{O}\right), 85.6(\mathrm{C}-10), 67.4(\mathrm{C}-12), 56.3\left(\mathrm{OCH}_{3}\right)$, $36.2(\mathrm{C}-11)$, $34.6\left(\mathrm{CH}_{2}\right), 34.5(\mathrm{C}-9), 28.8\left(\mathrm{CH}_{2}\right), 25.9\left(\mathrm{CH}_{2}\right), 23.6\left(\mathrm{CH}_{2}\right)$, $15.1\left(\mathrm{CH}_{3}\right.$ at $\left.\mathrm{C}-11\right), 14.6\left(\mathrm{CH}_{3}\right.$ at $\left.\mathrm{C}-9\right)$; HRMS-ESI: calcd for $\mathrm{C}_{15} \mathrm{H}_{26} \mathrm{O}_{4} \mathrm{Na}$ : 293.1729; Found: 293.1731.

(9S,10R,11R,E)-10-(methoxymethoxy)-9,11-dimethyloxacyclododec7-en-2-one (MGSTA-12). ${ }^{1} \mathrm{H} \mathrm{NMR}\left(\mathrm{CDCl}_{3}, 500 \mathrm{MHz}\right) \delta 5.42$ (ddd, $1 \mathrm{H}, \mathrm{J}_{7,8}$ $=14.9,8.3,6.3 \mathrm{~Hz}, \mathrm{H}-7), 5.25\left(\mathrm{dd}, 1 \mathrm{H}, J_{8,9}=8.2 \mathrm{~Hz}, \mathrm{H}-8\right), 4.70-4.66(\mathrm{~m}$, $2 \mathrm{H}, \mathrm{OCH}_{2} \mathrm{O}$ ), 4.47 (dd, $1 \mathrm{H}, J_{12,12^{\prime}}=10.6, J_{11,12}=2.9 \mathrm{~Hz}, \mathrm{H}-12$ ), 3.54 (appt, $\left.1 \mathrm{H}, J_{12,12^{\prime}}=J_{11,12^{\prime}}=10.7 \mathrm{~Hz}, \mathrm{H}-12^{\prime}\right), 3.40\left(\mathrm{~s}, 3 \mathrm{H}, \mathrm{OCH}_{3}\right), 3.32(\mathrm{~d}, 1 \mathrm{H}, J=$ $10.1 \mathrm{~Hz}, \mathrm{H}-10), 2.46-2.38\left(\mathrm{~m}, 1 \mathrm{H}, \mathrm{CH}_{2}\right), 2.17-2.06(\mathrm{~m}, 3 \mathrm{H}, \mathrm{H}-9$ and $\left.\mathrm{CH}_{2}\right), 2.02-1.93(\mathrm{~m}, 1 \mathrm{H}, \mathrm{H}-11), 1.74-1.61\left(\mathrm{~m}, 4 \mathrm{H}, \mathrm{CH}_{2}\right), 1.20-1.12$ (m, $\left.1 \mathrm{H}, \mathrm{CH}_{2}\right), 1.06\left(\mathrm{~d}, 3 \mathrm{H}, \mathrm{J}=6.8 \mathrm{~Hz}, \mathrm{CH}_{3}\right.$ at C-9), $0.89(\mathrm{~d}, 3 \mathrm{H}, \mathrm{J}=7.3 \mathrm{~Hz}$, $\mathrm{CH}_{3}$ at $\left.\mathrm{C}-11\right) ;{ }^{13} \mathrm{C} \mathrm{NMR}\left(\mathrm{CDCl}_{3}, 125 \mathrm{MHz}\right) \delta 173.4(\mathrm{C}-2), 135.5$ (C-7), 131.4 (C-8), $98.7\left(\mathrm{OCH}_{2} \mathrm{O}\right), 83.9$ (C-10), $66.5(\mathrm{C}-12), 56.0\left(\mathrm{OCH}_{3}\right), 40.4$ (C-9), 35.7 (C-11), $34.7\left(\mathrm{CH}_{2}\right), 30.4\left(\mathrm{CH}_{2}\right), 26.9\left(\mathrm{CH}_{2}\right), 22.6\left(\mathrm{CH}_{2}\right), 17.2$ $\left(\mathrm{CH}_{3}\right.$ at $\left.\mathrm{C}-9\right), 10.6\left(\mathrm{CH}_{3}\right.$ at $\left.\mathrm{C}-11\right)$; HRMS-ESI: calcd for $\mathrm{C}_{15} \mathrm{H}_{26} \mathrm{O}_{4} \mathrm{Na}$ : 293.1729; Found: 293.1732.

(9S,10R,11R,Z)-10-hydroxy-9,11-dimethyloxacyclododec-7-en-2-one (MGSTA-13). To stirred MGSTA-11 (28.1 mg; $0.104 \mathrm{mmol}$ ) in $\mathrm{CH}_{2} \mathrm{Cl}_{2}$ (5 $\mathrm{mL}), \operatorname{TMSBr}(20.6 \mu \mathrm{L} ; 0.0156 \mathrm{mmol})$ was added at $-20^{\circ} \mathrm{C}$. The mixture was stirred for $1 \mathrm{~h}$. Satd $\mathrm{NaHCO}_{3}$ was then added and the solution was extracted with $\mathrm{CH}_{2} \mathrm{Cl}_{2}$ ( $\left.3 \times 10 \mathrm{~mL}\right)$. The combined organic layers were dried and the solvent was removed under reduced pressure. Purification by FC (EtOAc/Cy 1:8) gave MGSTA-13 (18.2 mg, $77 \%$ ) as a colourless oil. $[\mathrm{a}]_{\mathrm{D}}-20^{\circ}$ (c 1.5, $\left.\mathrm{CHCl}_{3}\right) ;{ }^{1} \mathrm{H} \mathrm{NMR}\left(\mathrm{CDCl}_{3}, 500 \mathrm{MHz}\right) \delta 5.54-5.47(\mathrm{~m}, 1 \mathrm{H}$, $\mathrm{H}-8$ ), 5.39 (td, $1 \mathrm{H}, J_{7,8}=10.6, J_{6,7}=5.3 \mathrm{~Hz}, \mathrm{H}-7$ ), 4.47 (dd, $1 \mathrm{H}, J_{12,12^{\prime}}=$ 11.5, $\left.J_{12,11}=3.4 \mathrm{~Hz}, \mathrm{H}-12\right), 3.82\left(\mathrm{dd}, 1 \mathrm{H}, J_{11,12^{\prime}}=4.5 \mathrm{~Hz}, \mathrm{H}-12^{\prime}\right), 3.54$ (ddd, $1 \mathrm{H}, J_{10,11}=7.6, J_{10, O H}=4.9, J_{9,10}=2.2 \mathrm{~Hz}, \mathrm{H}-10$ ), 2.73 (dqd, $1 \mathrm{H}, J_{8,9}$ $=9.2, J_{g, M e}=6.8 \mathrm{~Hz}, \mathrm{H}-9$ ), 2.42 (ddd, $1 \mathrm{H}, J=12.9,8.8,4.0 \mathrm{~Hz}, \mathrm{CH}_{2}$ ), 2.33 (ddd, $1 \mathrm{H}, J=13.1,8.8,3.7 \mathrm{~Hz}, \mathrm{CH}_{2}$ ), $2.24-2.14\left(\mathrm{~m}, 1 \mathrm{H}, \mathrm{CH}_{2}\right.$ ), 2.01 $-1.93(\mathrm{~m}, 1 \mathrm{H}, \mathrm{H}-11), 1.91-1.84\left(\mathrm{~m}, 1 \mathrm{H}, \mathrm{CH}_{2}\right), 1.83-1.74\left(\mathrm{~m}, 1 \mathrm{H}, \mathrm{CH}_{2}\right)$, $1.70-1.63\left(\mathrm{~m}, 2 \mathrm{H}, \mathrm{CH}_{2}\right), 1.43(\mathrm{~d}, 1 \mathrm{H}, \mathrm{OH}), 1.37-1.28\left(\mathrm{~m}, 1 \mathrm{H}, \mathrm{CH}_{2}\right)$, $1.14\left(\mathrm{~d}, 3 \mathrm{H}, J_{11, M e}=7.0 \mathrm{~Hz}, \mathrm{CH}_{3}\right.$ at $\left.\mathrm{C}-11\right), 0.96\left(\mathrm{~d}, 3 \mathrm{H}, \mathrm{CH}_{3}\right.$ at $\left.\mathrm{C}-9\right) ;{ }^{13} \mathrm{C}$ 
NMR ( $\left.\mathrm{CDCl}_{3}, 125 \mathrm{MHz}\right) \delta 174.6$ (C-2), 135.5 (C-8), 128.9 (C-7), 78.4 (C10), 67.4 (C-12), $36.3(\mathrm{C}-11), 34.8\left(\mathrm{CH}_{2}\right), 33.8(\mathrm{C}-9), 28.8\left(\mathrm{CH}_{2}\right), 26.1$ $\left(\mathrm{CH}_{2}\right), 23.7\left(\mathrm{CH}_{2}\right), 15.0\left(\mathrm{CH}_{3}\right.$ at $\left.\mathrm{C}-11\right), 12.8\left(\mathrm{CH}_{3}\right.$ at C-9); HRMS-ESI: calcd for $\mathrm{C}_{15} \mathrm{H}_{25} \mathrm{NO}_{3} \mathrm{Na}$ : 290.1732; Found: 290.1726.

(9S,10R,11R,E)-10-hydroxy-9,11-dimethyloxacyclododec-7-en-2-one (MGSTA-14). To stirred MGSTA-12 (23.4 mg; $0.087 \mathrm{mmol}$ ) in $\mathrm{CH}_{2} \mathrm{Cl}_{2}$ (6 $\mathrm{mL}), \operatorname{TMSBr}(23 \mu \mathrm{L} ; 0.174 \mathrm{mmol})$ was added at $-20^{\circ} \mathrm{C}$. The mixture was stirred for $2 \mathrm{~h}$. Satd $\mathrm{NaHCO}_{3}$ was added and the solution was extracted with $\mathrm{CH}_{2} \mathrm{Cl}_{2}(3 \times 10 \mathrm{~mL})$ and the combined organic layers were dried and the solvent was removed under reduced pressure. Purification by FC (EtOAc/Cy 1:10) gave MGSTA-14 (14.5 mg, $74 \%$ ) as a colourless oil. [a]D $6.49^{\circ}$ (c 0.99, $\mathrm{CHCl}_{3}$ ); ${ }^{1} \mathrm{H}$ NMR $\left(\mathrm{CDCl}_{3}, 500 \mathrm{MHz}\right) \delta 5.44$ (ddd, $1 \mathrm{H}$ $\left.J_{7,8}=14.6, J_{7,6}=8.0, J_{7,6^{\prime}}=6.4 \mathrm{~Hz}, \mathrm{H}-7\right), 5.28\left(\mathrm{dd}, 1 \mathrm{H}, J_{8,9}=8.1 \mathrm{~Hz}, \mathrm{H}-8\right)$ 4.41 (dd, $1 \mathrm{H}, J_{12,12^{\prime}}=10.7,2.8 \mathrm{~Hz}, \mathrm{H}-12$ ), $3.56(\mathrm{t}, 1 \mathrm{H}, \mathrm{H}-12$ '), 3.43 (dd, $\left.1 \mathrm{H}, J=9.7, J_{10, \mathrm{OH}}=6.4 \mathrm{~Hz}, \mathrm{H}-10\right), 2.44-2.36\left(\mathrm{~m}, 1 \mathrm{H}, \mathrm{CH}_{2}\right), 2.16-2.06$ $\left(\mathrm{m}, 3 \mathrm{H}, \mathrm{H}-9\right.$ and $\left.\mathrm{CH}_{2}\right), 2.03-1.96(\mathrm{~m}, 1 \mathrm{H}, \mathrm{H}-11), 1.74-1.62(\mathrm{~m}, 4 \mathrm{H}$ $\left.\mathrm{CH}_{2}\right), 1.45(\mathrm{~d}, 1 \mathrm{H}, \mathrm{OH}), 1.20-1.12\left(\mathrm{~m}, 1 \mathrm{H}, \mathrm{CH}_{2}\right), 1.09(\mathrm{~d}, 3 \mathrm{H}, \mathrm{Jg}, \mathrm{Me}=6.8$ $\mathrm{Hz}, \mathrm{CH}_{3}$ at $\mathrm{C}-9$ ), 0.88 (d, $3 \mathrm{H}, J_{11, M e}=7.3 \mathrm{~Hz}, \mathrm{CH}_{3}$ at $\mathrm{C}-11$ ); ${ }^{13} \mathrm{C} \mathrm{NMR}$ $\left(\mathrm{CDCl}_{3}, 125 \mathrm{MHz}\right) \delta 173.4$ (C-2), 135.3 (C-8), 131.2 (C-7), 76.3 (C-10), 66.6 (C-12), 39.9 (C-9), $35.9(\mathrm{C}-11), 34.9\left(\mathrm{CH}_{2}\right), 30.2\left(\mathrm{CH}_{2}\right), 27.4\left(\mathrm{CH}_{2}\right)$, $22.5\left(\mathrm{CH}_{2}\right), 16.8\left(\mathrm{CH}_{3}\right.$ at $\left.\mathrm{C}-9\right), 10.0\left(\mathrm{CH}_{3}\right.$ at C-11); HRMS-ESI: calcd for $\mathrm{C}_{13} \mathrm{H}_{22} \mathrm{O}_{3} \mathrm{Na}$ : 249.1467; Found: 249.1459 .

\section{(7E,9S,10R,11R,12Z)-10-hydroxy-9,11,13-}

trimethyloxacyclotetradeca-7,12-dien-2-one (MGSTA-15). To a stirred solution of 34 (8.7 mg; $0.028 \mathrm{mmol})$ in $\mathrm{CH}_{2} \mathrm{Cl}_{2}(5 \mathrm{~mL}), \mathrm{TMSBr}(5.5 \mu \mathrm{L}$; $0.042 \mathrm{mmol}$ ) was added at $-15^{\circ} \mathrm{C}$. The mixture was stirred for $3 \mathrm{~h}$. Satd $\mathrm{NaHCO}_{3}$ was added and the solution was extracted with $\mathrm{CH}_{2} \mathrm{Cl}_{2}(3 \times 10$ $\mathrm{mL}$ ). The combined organic layers were dried and the solvent was removed under reduced pressure. Purification by FC (EtOAc/Cy 1:7) gave MGSTA-15 (4.5 mg, 60\%) as a colourless oil; [ $\alpha]_{D} 37.6^{\circ}$ (c 0.19 , $\left.\mathrm{CHCl}_{3}\right) ;{ }^{1} \mathrm{H} \mathrm{NMR}\left(\mathrm{CDCl}_{3}, 500 \mathrm{MHz}\right) \delta 5.60\left(\mathrm{dt}, 1 \mathrm{H}, J_{11,12}=10.2, J_{12, \mathrm{Me}}=\right.$ $1.4 \mathrm{~Hz}, \mathrm{H}-12$ ), 5.46 (ddd, $1 \mathrm{H}, J 7,8=15.3, J=7.8, J=5.8 \mathrm{~Hz}, \mathrm{H}-7$ ), 5.30 (ddt, $1 \mathrm{H}, J=8.6, J=1.3 \mathrm{~Hz}, \mathrm{H}-8$ ), $4.56\left(\mathrm{dd}, 1 \mathrm{H}, J_{14,14^{\prime}}=13.1, J=1.0 \mathrm{~Hz}\right.$, $\mathrm{H}-14$ ), 4.34 (d, 1H, H-14'), 3.24 (d, 1H, J = 9.3 Hz, H-10), $3.02-2.95$ (m, $1 \mathrm{H}, \mathrm{H}-11), 2.46-2.39\left(\mathrm{~m}, 1 \mathrm{H}, \mathrm{CH}_{2}\right), 2.30-2.18\left(\mathrm{~m}, 2 \mathrm{H}, \mathrm{H}-9\right.$ and $\left.\mathrm{CH}_{2}\right)$, $2.17-2.10\left(\mathrm{~m}, 1 \mathrm{H}, \mathrm{CH}_{2}\right), 1.98-1.90\left(\mathrm{~m}, 1 \mathrm{H}, \mathrm{CH}_{2}\right), 1.82-1.77(\mathrm{~m}, 1 \mathrm{H}$, $\left.\mathrm{CH}_{2}\right), 1.76\left(\mathrm{~d}, 3 \mathrm{H}, \mathrm{CH}_{3}\right.$ at C-13), $1.64-1.57\left(\mathrm{~m}, 1 \mathrm{H}, \mathrm{CH}_{2}\right), 1.53-1.47(\mathrm{~m}$ $\left.1 \mathrm{H}, \mathrm{CH}_{2}\right), 1.41-1.32(\mathrm{~m}, 1 \mathrm{H} \mathrm{CH}), 1.09\left(\mathrm{~d}, 3 \mathrm{H}, \mathrm{Jg}_{9, \mathrm{Me}}=6.7 \mathrm{~Hz}, \mathrm{CH}_{3}\right.$ at C9), $0.92\left(\mathrm{~d}, 3 \mathrm{H}, J_{11, \mathrm{Me}}=7.0 \mathrm{~Hz}, \mathrm{CH}_{3}\right.$ at C-11); ${ }^{13} \mathrm{C} \mathrm{NMR}\left(\mathrm{CDCl}_{3}, 125 \mathrm{MHz}\right)$ б 174.0 (C-2), 134.7 (C-12), 133.9 (C-8), 129.9 (C-7), 127.5 (C-13), 78.9 (C-10), 65.0 (C-14), $41.4(\mathrm{C}-9), 34.6(\mathrm{C}-11), 34.0\left(\mathrm{CH}_{2}\right), 30.0\left(\mathrm{CH}_{2}\right), 27.6$ $\left(\mathrm{CH}_{2}\right), 23.5\left(\mathrm{CH}_{2}\right), 23.4\left(\mathrm{CH}_{3}\right.$ at $\left.\mathrm{C}-13\right), 18.1\left(\mathrm{CH}_{3}\right.$ at $\left.\mathrm{C}-9\right), 12.9\left(\mathrm{CH}_{3}\right.$ at $\mathrm{C}$ 11); HRMS-ESI: calcd for $\mathrm{C}_{16} \mathrm{H}_{26} \mathrm{O}_{3} \mathrm{Na}$ : 289.1780; Found: 289.1775.

\section{(4Z,6R,7S,8S,9E)-7-O-(methyl}

2',3',4'-tri-O-benzoyl- $\beta$-Dglucopyranosyluronate)-4,6-dimethylcyclotetradeca-8-methoxy-4,9dienone (37). To stirred macroketone MGSTA-5 (5 mg, $18 \mu \mathrm{mol})$, the trichloroacetimidate $36(24 \mathrm{mg}, 36 \mu \mathrm{mol})$, and powdered molecular sieves $4 \mathrm{~A}(25 \mathrm{mg})$ in dry $\mathrm{CH}_{2} \mathrm{Cl}_{2}(0.5 \mathrm{~mL})$ was cooled to $-40{ }^{\circ} \mathrm{C}$ under nitrogen atmosphere. To this mixture was added $10 \%$ TMSOTf in $\mathrm{CH}_{2} \mathrm{Cl}_{2}$ $(11 \mu \mathrm{L}, 7.2 \mu \mathrm{mol})$ drop wisely, and the mixture was stirred at $-40^{\circ} \mathrm{C}$ for 5 $\mathrm{h}$, and then EtOAc was added ( $1 \mu \mathrm{L}, 7.2 \mu \mathrm{mol})$. The mixture was filtered and concentrated. FC of the residue (PE/EtOAc $4: 1)$ gave $37(8 \mathrm{mg}$, $57 \%$ ); $[\alpha]_{0}-9.4^{\circ}$ (c $0.58, \mathrm{CHCl}_{3}$ ); ${ }^{1} \mathrm{H} \mathrm{NMR}\left(\mathrm{CDCl}_{3}, 500 \mathrm{MHz}\right.$ ): $\delta 8.00-8.00$ $(\mathrm{m}, 2 \mathrm{H}, \operatorname{Ar} H), 7.93-7.91(\mathrm{~m}, 2 \mathrm{H}, \operatorname{Ar} H), 7.88-7.81(\mathrm{~m}, 2 \mathrm{H}, \operatorname{Ar} H), 7.53-$ $7.36(\mathrm{~m}, 7 \mathrm{H}, \mathrm{ArH}), 7.31-7.28(\mathrm{~m}, 2 \mathrm{H}, \mathrm{ArH}), 5.94$ (appt, $1 \mathrm{H}, J_{2^{\prime}, 3^{\prime}}=J_{3^{\prime}, 4^{\prime}}=$ $\left.9.6 \mathrm{~Hz}, \mathrm{H}-3^{\prime}\right), 5.69\left(\mathrm{dd}, 1 \mathrm{H}, J_{3^{\prime}, 4^{\prime}}=J_{4^{\prime}, 5^{\prime}}=9.7 \mathrm{~Hz}, \mathrm{H}-4^{\prime}\right), 5.62-5.52(\mathrm{~m}, 3 \mathrm{H}$ H-2', H-5,10), 5.23 (dd, $1 \mathrm{H}, J_{9,10 \text { trans }}=15.7, J_{8,9}=7.5 \mathrm{~Hz}, \mathrm{H}-9$ ), 5.21 (d, $\left.1 \mathrm{H}, J^{\prime}, 2^{\prime}=7.9 \mathrm{~Hz}, \mathrm{H}-1^{\prime}\right), 4.27$ (d, 1H, H-5'), 3.69 (s, 3H, OMe), $3.48-$
3.38 (m, 2H, H-7,8), 2.87 (s, 3H, OMe), $2.56-2.41$ (m, 2H, H-6, CH $\mathrm{CH}_{2}$, $2.40-2.30\left(\mathrm{~m} \mathrm{2H}, \mathrm{CH}_{2}\right), 2.28-2.06\left(\mathrm{~m}, 5 \mathrm{H}, \mathrm{CH}_{2}\right), 1.70(\mathrm{~d}, 3 \mathrm{H}, \mathrm{J}=1.5$ $\mathrm{Hz}, M e$ at C-4), $1.68-1.57$ (m, 2H, CH ), $1.52-1.45$ (m, 2H, CH$)_{2}, 0.91$ (d, $3 \mathrm{H}, \mathrm{J}_{6, \mathrm{Me}}=6.8 \mathrm{~Hz}, \mathrm{Me}$ at $\left.\mathrm{C}-6\right) ;{ }^{13} \mathrm{C}$ NMR $\left(125 \mathrm{MHz}, \mathrm{CDCl}_{3}\right): \delta 212.3$ (C-1), $167.6(\mathrm{C}=\mathrm{O}), 165.9(\mathrm{C}=\mathrm{O}), 165.4(\mathrm{C}=0), 165.0(\mathrm{C}=\mathrm{O}), 134.5$ $(\mathrm{C}=\mathrm{C}), 133.5(\mathrm{ArCH}), 133.4(\mathrm{ArCH}), 133.2(\mathrm{ArCH}), 132.0(\mathrm{Cq}), 130.5$ $(\mathrm{C}=\mathrm{C}), 130.0(\mathrm{ArCH}), 130.0(\mathrm{ArCH}), 129.9(\mathrm{ArCH}), 129.8(\mathrm{Cq}), 129.4(\mathrm{C}-$ 9), $129.1(\mathrm{Cq}), 129.1(\mathrm{Cq}), 128.6(\mathrm{ArCH}), 128.5(\mathrm{ArCH}), 128.4(\mathrm{ArCH})$, 101.5 (C-1') , 84.9 (C-7 or 8), 84.5 (C-7 or 8), 72.9 (C-5), 72.7 (C-3'), 72.1 (C-2'), 70.8 (C-4'), $56.5\left(\mathrm{OCH}_{3}\right), 52.9\left(\mathrm{OCH}_{3}\right), 42.3\left(\mathrm{CH}_{2}\right), 41.0$ $\left(\mathrm{CH}_{2}\right), 33.2(\mathrm{C}-6), 30.5\left(\mathrm{CH}_{2}\right), 28.8\left(\mathrm{CH}_{2}\right), 27.2\left(\mathrm{CH}_{2}\right), 23.4\left(\mathrm{CH}_{2}\right), 23.2$ $\left(\mathrm{CH}_{3}\right.$ at C-4), $13.5\left(\mathrm{CH}_{3}\right.$ at C-6); HRMS-ESI: calcd for $\mathrm{C}_{45} \mathrm{H}_{50} \mathrm{O}_{12} \mathrm{Na}$ : 805.3200; Found: 805.3202.

(4Z,6R,7S,8S,9E)-7-O-( $\beta$-D-glucopyranosyluronic acid)-4,6dimethylcyclotetradeca-8-methoxy-4,9-dienone (MGSTA-16). To stirred 37 (12.7 mg; $16 \mu \mathrm{mol})$ in $\mathrm{MeOH}(1.2 \mathrm{~mL}), \mathrm{NaOH}_{(\mathrm{aq})} 5 \%(48 \mu \mathrm{L}, 59$ $\mu \mathrm{mol})$ wad added. The resulting solution was stirred at RT for $20 \mathrm{~h}$. A solution of $1 \mathrm{M} \mathrm{AcOH}$ was added until the $\mathrm{pH}$ was 7 . The solvent was removed under reduced pressure and the residue was passed through silica gel 100 C18-reversed phase column $\left(\mathrm{H}_{2} \mathrm{O}\right.$ to $\mathrm{H}_{2} \mathrm{O} / \mathrm{MeOH} 4: 1$ to $\mathrm{H}_{2} \mathrm{O} / \mathrm{MeOH} 2: 1$ to $\mathrm{H}_{2} \mathrm{O} / \mathrm{MeOH} 1: 1$ to $\mathrm{H}_{2} \mathrm{O} / \mathrm{MeOH} 1: 2$ to $\mathrm{MeOH}$ ). The residue was subjected to vacuum distillation to remove the aromatic impurities and then passed again through silica gel $100 \mathrm{C} 18$-reverse phase silica (eluant, $\mathrm{H}_{2} \mathrm{O}$ to $\mathrm{H}_{2} \mathrm{O} / \mathrm{MeOH} 4: 1$ to $\mathrm{H}_{2} \mathrm{O} / \mathrm{MeOH} 2: 1$ to $\mathrm{H}_{2} \mathrm{O} / \mathrm{MeOH}$ 1:1 to $\mathrm{H}_{2} \mathrm{O} / \mathrm{MeOH} 1: 2$ to $\mathrm{MeOH}$ ) to give MGSTA-16 (5.3 mg; $73 \%$ ); $[\alpha]_{D}+5.32^{\circ}$ (c 0.36, $\left.\mathrm{MeOH}\right) ;{ }^{1} \mathrm{H} \mathrm{NMR}\left(\mathrm{CDCl}_{3}, 500 \mathrm{MHz}\right): 5.85$ (ddd, $\left.1 \mathrm{H}, J_{9,10}=15.0,9.6,4.8 \mathrm{~Hz}, \mathrm{H}-10\right), 5.44\left(\mathrm{dd}, 1 \mathrm{H}, J_{8,9}=9.0 \mathrm{~Hz}, \mathrm{H}-9\right)$, $5.37\left(\mathrm{~d}, 1 \mathrm{H}, J_{5,6}=9.2 \mathrm{~Hz}, \mathrm{H}-5\right), 4.44\left(\mathrm{~d}, 1 \mathrm{H}, J^{\prime}, 2^{\prime}=7.9 \mathrm{~Hz}, \mathrm{H}-1^{\prime}\right), 3.85$ (appt, 1H, H-8), $3.60\left(\mathrm{~d}, 1 \mathrm{H}, J_{4^{\prime}, 5^{\prime}}=9.3 \mathrm{~Hz}, \mathrm{H}-5^{\prime}\right), 3.56-3.46(\mathrm{~m}, 3 \mathrm{H}, \mathrm{H}-$ 7,3', $4^{\prime}$ ), 3.37 (dd, $\left.1 \mathrm{H}, J_{2^{\prime}, 3^{\prime}}=7.8 \mathrm{~Hz}, \mathrm{H}-2^{\prime}\right), 3.32\left(\mathrm{~s}, 3 \mathrm{H}, \mathrm{OCH}_{3}\right), 2.96(\mathrm{~m}$, $\left.1 \mathrm{H}, \mathrm{CH}_{2}\right), 2.69\left(\mathrm{~m}, 1 \mathrm{H}, \mathrm{CH}_{2}\right), 2.42\left(\mathrm{~m}, 1 \mathrm{H}, \mathrm{CH}_{2}\right), 2.35-2.16\left(\mathrm{~m}, 6 \mathrm{H}, \mathrm{CH}_{2}\right.$, $\mathrm{H}-6), 1.71-1.60\left(\mathrm{~m}, 5 \mathrm{H}\right.$, Me at C-4, $\left.\mathrm{CH}_{2}\right), 1.50\left(\mathrm{~m}, 1 \mathrm{H}, \mathrm{CH}_{2}\right), 1.36-1.25$ (m, $\left.1 \mathrm{H}, \mathrm{CH}_{2}\right), 0.87\left(\mathrm{~d}, 3 \mathrm{H}, \mathrm{JMe}_{\mathrm{e}, 6}=6.7 \mathrm{~Hz}\right.$, Me at C-6); ${ }^{13} \mathrm{C} \mathrm{NMR}(125 \mathrm{MHz}$, $\mathrm{CDCl}_{3}$ ): $\delta 218.8$ (C-1), 175.4 (C-6'), 137.2 (C-10), 133.1 (C-4), 130.5 (C5), $127.0(\mathrm{C}-9), 104.3\left(\mathrm{C}-1^{\prime}\right), 87.7(\mathrm{CH}), 84.4(\mathrm{C}-8), 76.9\left(\mathrm{C}-5^{\prime}\right), 75.4(\mathrm{CH})$, $73.8(\mathrm{C}-2), 71.9(\mathrm{CH}), 55.5\left(\mathrm{OCH}_{3}\right), 40.4\left(\mathrm{CH}_{2}\right), 38.7\left(\mathrm{CH}_{2}\right), 32.9(\mathrm{C}-6)$, $29.1\left(\mathrm{CH}_{2}\right), 28.6\left(\mathrm{CH}_{2}\right), 24.7\left(\mathrm{CH}_{2}\right), 22.1(\mathrm{Me}$ at $\mathrm{C}-4), 20.5\left(\mathrm{CH}_{2}\right), 12.2$ (Me at C-6); HRMS-ESI: calcd for $\mathrm{C}_{23} \mathrm{H}_{36} \mathrm{O}_{9} \mathrm{Na}$ : 479.2257; Found: 479.2263

\section{(4Z,6R,7S,8S,9E)-7-O-(methyl 2' 3',4'-tri-O-benzoyl-a-D-} glucopyranosyl uronate)-4,6-dimethylcyclotetradeca-8-methoxy-4,9dienone (38). To stirred 37 (20.8 mg; $27 \mu \mathrm{mol})$, in $\mathrm{CDCl}_{3}(0.75 \mathrm{~mL})$, TiCl 4 ( $66 \mu \mathrm{L} ; 54 \mu \mathrm{mol} ; 0.82 \mathrm{M}$ in $\mathrm{CDCl}_{3}$ ) was added. After storage for $12 \mathrm{~h}$ at 4 ${ }^{\circ} \mathrm{C}$, the solution was diluted with $\mathrm{CH}_{2} \mathrm{Cl}_{2}$ and quenched with $\mathrm{NaHCO}_{3}$. The organic layers were collected, dried over $\mathrm{Na}_{2} \mathrm{SO}_{4}$, filtered and the solvent was removed under reduced pressure. FC of the residue (PE/EtOAc 4:1) gave 38 (14.5 mg, 69\%); $[\alpha]_{D}+33.4^{\circ}$ (c 0.75, $\left.\mathrm{CHCl}_{3}\right) ;{ }^{1} \mathrm{H}$ $\mathrm{NMR}\left(\mathrm{CDCl}_{3}, 500 \mathrm{MHz}\right): \delta 8.05-7.99(\mathrm{~m}, 2 \mathrm{H}, \mathrm{ArH}), 8.00-7.94(\mathrm{~m}, 2 \mathrm{H}$, $\operatorname{ArH}), 7.92-7.85(\mathrm{~m}, 2 \mathrm{H}, \mathrm{ArH}), 7.56-7.48(\mathrm{~m}, 2 \mathrm{H}, \mathrm{ArH}), 7.47-7.35(\mathrm{~m}, 5 \mathrm{H}$, $\operatorname{ArH}), 7.30(\mathrm{~m}, 2 \mathrm{H}, \mathrm{ArH}), 6.27$ (appt, $\left.1 \mathrm{H}, J_{2^{\prime}, 3^{\prime}}=J_{3^{\prime}, 4^{\prime}}=9.9 \mathrm{~Hz}, \mathrm{H}-3^{\prime}\right), 5.71$ (ddd, $\left.1 \mathrm{H}, \mathrm{J}_{9,10}=14.9,8.4,5.9 \mathrm{~Hz}, \mathrm{H}-10\right), 5.58\left(\mathrm{t}, 1 \mathrm{H}, J_{4^{\prime}, 5^{\prime}}=10.0 \mathrm{~Hz}, \mathrm{H}-\right.$ $\left.4^{\prime}\right), 5.45\left(\mathrm{~d}, 1 \mathrm{H}, J^{\prime}, 2^{\prime}=3.7 \mathrm{~Hz}, \mathrm{H}-1^{\prime}\right), 5.37$ (dd, $\left.1 \mathrm{H}, \mathrm{H}-2^{\prime}\right), 5.31$ (dd, $1 \mathrm{H}, J_{8,9}$ $=8.1 \mathrm{~Hz}, \mathrm{H}-9), 5.21\left(\mathrm{~d}, 1 \mathrm{H}, \mathrm{H}-5^{\prime}\right), 4.80\left(\mathrm{~d}, 1 \mathrm{H}, J_{5,6}=9.6 \mathrm{~Hz}, \mathrm{H}-5\right), 3.70$ (appt, 1H, H-8), 3.67 (s, 3H, OCH $H_{3}, 3.56\left(\mathrm{~d}, 1 \mathrm{H}, \mathrm{J}_{7,8}=9.1 \mathrm{~Hz}, \mathrm{H}-7\right), 3.27$ (s, $\left.3 \mathrm{H}, \mathrm{OCH}_{3}\right), 2.63-2.57\left(\mathrm{~m}, 1 \mathrm{H}, \mathrm{CH}_{2}\right), 2.38-2.07\left(\mathrm{~m}, 7 \mathrm{H}, \mathrm{H}-6, \mathrm{CH}_{2}\right)$, 1.98-1.93 (m, $\left.1 \mathrm{H}, \mathrm{CH}_{2}\right), 1.67-1.57\left(\mathrm{~m}, 2 \mathrm{H}, \mathrm{CH}_{2}\right), 1.48-1.38\left(\mathrm{~m}, 2 \mathrm{H}, \mathrm{CH}_{2}\right)$, $1.42\left(\mathrm{~d}, 3 \mathrm{H}, \mathrm{JMe}_{\mathrm{e}}=5.8 \mathrm{~Hz}, \mathrm{Me}\right.$ at C-4), $0.85\left(\mathrm{~d}, 3 \mathrm{H}, \mathrm{JMe}_{\mathrm{e}, 6}=6.6 \mathrm{~Hz}, \mathrm{Me}\right.$ at C-6); ${ }^{13} \mathrm{C}$ NMR (125 MHz, $\mathrm{CDCl}_{3}$ ): $\delta 211.1$ (C-1), 169.1 (C=O), 166.0 
$(C=0), 165.7(C=0), 165.6(C=0), 134.9(\mathrm{C}-10), 134.0(C q), 133.7$ ( $\mathrm{ArCH}), 133.4(\mathrm{ArCH}), 133.4(\mathrm{ArCH}), 130.1(\mathrm{ArCH}), 129.9(\mathrm{ArCH}), 129.9$ ( $\mathrm{ArCH}), 129.6$ (C-5), 129.3 (Cq), 129.3 (Cq), 129.1 (C-9), 129.0 (Cq), 128.7 ( $\mathrm{ArCH}), 128.6(\mathrm{ArCH}), 128.5(\mathrm{ArCH}), 97.3\left(\mathrm{C}-1^{\prime}\right), 86.2(\mathrm{C}-7), 82.6$ (C-8), 71.8 (C-2'), 70.9 (C-4'), 70.0 (C-3'), $68.7\left(\mathrm{C}^{\prime} 5^{\prime}\right), 56.1\left(\mathrm{OCH}_{3}\right), 52.8$ $\left(\mathrm{OCH}_{3}\right), 40.8\left(\mathrm{CH}_{2}\right), 40.3\left(\mathrm{CH}_{2}\right), 33.9(\mathrm{C}-6), 30.2\left(\mathrm{CH}_{2}\right), 29.0\left(\mathrm{CH}_{2}\right), 26.3$ $\left(\mathrm{CH}_{2}\right), 22.8$ (Me at C-4), $22.2\left(\mathrm{CH}_{2}\right), 12.8$ (Me at C-6); HRMS-ESI: calcd for $\mathrm{C}_{45} \mathrm{H}_{50} \mathrm{O}_{12} \mathrm{Na}$ : 805.3200; Found: 805.3212.

(4Z,6R,7S,8S,9E)-7-O-( $\alpha$-D-glucopyranosyluronic

acid)-4,6dimethylcyclotetradeca-8-methoxy-4,9-dienone (MGSTA-17). To stirred 38 (9 mg; $11.5 \mu \mathrm{mol})$ in $\mathrm{MeOH}(0.8 \mathrm{~mL}), \mathrm{NaOH}_{(\mathrm{aq})} 5 \%(26.2 \mu \mathrm{L}$, $32.2 \mu \mathrm{mol}$ ) wad added. The resulting solution was stirred at RT for $48 \mathrm{~h}$. A solution of $1 \mathrm{M} \mathrm{AcOH}$ was added until the $\mathrm{pH}=7$. The solvent was removed under reduced pressure and the residue was passed through a silica gel $100 \mathrm{C} 18$-reversed phase column (eluant, $\mathrm{H}_{2} \mathrm{O}$ to $\mathrm{H}_{2} \mathrm{O} / \mathrm{MeOH} 4: 1$ to $\mathrm{H}_{2} \mathrm{O} / \mathrm{MeOH}$ 2:1 to $\mathrm{H}_{2} \mathrm{O} / \mathrm{MeOH} 1: 1$ to $\mathrm{H}_{2} \mathrm{O} / \mathrm{MeOH} 1: 2$ to $\mathrm{MeOH}$ ) to give MGSTA-17 (3.2 mg; 61\%); [a] $]_{\mathrm{D}}+63.2$ (c $\left.0.032, \mathrm{MeOH}\right) ;{ }^{1} \mathrm{H} \mathrm{NMR}\left(\mathrm{CDCl}_{3}\right.$, $500 \mathrm{MHz}$ ): 5.81 (ddd, $1 \mathrm{H}, \mathrm{J}_{9,10}=15.0,10.1,4.5 \mathrm{~Hz}, \mathrm{H}-10$ ), 5.46-5.39 (dd, $\left.1 \mathrm{H}, J_{8,9}=9.4 \mathrm{~Hz}, \mathrm{H}-9\right), 5.34(\mathrm{dd}, 1 \mathrm{H}, J=9.9,1.6 \mathrm{~Hz}, \mathrm{H}-5), 5.01(\mathrm{~d}, 1 \mathrm{H}$, $\left.J^{\prime}, 2^{\prime}=3.9 \mathrm{~Hz}, \mathrm{H}-1^{\prime}\right), 4.39\left(\mathrm{~d}, 1 \mathrm{H}, J^{\prime}, 5^{\prime}=10.2 \mathrm{~Hz}, \mathrm{H}-5^{\prime}\right), 3.81$ (dd, $1 \mathrm{H}, J_{2^{\prime}, 3}$ $\left.=9.9, J_{3^{\prime} 4^{\prime}}=8.9 \mathrm{~Hz}, \mathrm{H}-3^{\prime}\right) 3.74-3.71$ (appt, $\left.1 \mathrm{H}, \mathrm{H}-8^{\prime}\right), 3.56$ (m, 2H, H-7,2') $3.48\left(\mathrm{dd}, 1 \mathrm{H}, J_{3^{\prime}, 4^{\prime}}=9.0 \mathrm{~Hz}, \mathrm{H}-4^{\prime}\right), 3.29\left(\mathrm{~s}, 3 \mathrm{H}, \mathrm{OCH}_{3}\right), 3.12-3.05(\mathrm{~m}, 1 \mathrm{H}$, $\left.\mathrm{CH}_{2}\right)$, 2.78-2.73 (m, 1H, CH2), 2.58-2.52(m, 1H, CH2), 2.36-2.10 (m, 6H, $\left.\mathrm{H}-6, \mathrm{CH}_{2}\right), 1.72-1.62\left(\mathrm{~m}, 2 \mathrm{H}, \mathrm{CH}_{2}\right), 1.70(\mathrm{~d}, 3 \mathrm{H}, J=1.4 \mathrm{~Hz}, \mathrm{Me}$ at C-4), 1.53-1.44 (m, 1H, CH2), 1.27-1.13 (m, 1H, CH $\left.\mathrm{CH}_{2}\right), 0.89\left(\mathrm{~d}, 3 \mathrm{H}, \mathrm{J}_{6, \mathrm{Me}}=6.7\right.$ $\mathrm{Hz}, \mathrm{Me}$ at C-6); ${ }^{13} \mathrm{C} \mathrm{NMR}\left(125 \mathrm{MHz}, \mathrm{CDCl}_{3}\right): \delta 218.4$ (C-1), 175.7 (C-6'), 136.8 (C-10), 133.4 (C-4), 130.6 (C-5), 127.3 (C-9), 99.2 (C-1'), 84.4 (C7), 83.2 (C-8), 72.6 (C-3'), 71.9 (C-4'), 71.5 (C-2'), 71.3 (C-5'), 55.3 $\left(\mathrm{OCH}_{3}\right), 40.3\left(\mathrm{CH}_{2}\right), 37.8\left(\mathrm{CH}_{2}\right), 33.8(\mathrm{C}-6), 29.0\left(\mathrm{CH}_{2}\right), 28.7\left(\mathrm{CH}_{2}\right), 24.2$ $\left(\mathrm{CH}_{2}\right), 22.0$ (Me at C-4), $19.9\left(\mathrm{CH}_{2}\right), 12.0$ (Me at C-6); HRMS-ESI: calcd for $\mathrm{C}_{23} \mathrm{H}_{36} \mathrm{O} 9 \mathrm{Na}$ : 479.2257 ; Found: 479.2256 .

\section{MGSTA-18 and MGSTA-19.}

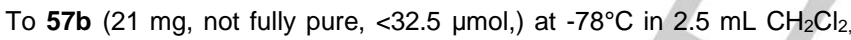
mCPBA ( $\leq 77 \%, 7.6 \mathrm{mg}, 33.9 \mu \mathrm{mol})$ in $\mathrm{CH}_{2} \mathrm{Cl}_{2}(2.5 \mathrm{~mL}$ ) was added. After 30 minutes at $-78^{\circ} \mathrm{C}$, TLC (PE/EtOAc 1:1.5) showed only baseline material. $\operatorname{Pr}_{2} \mathrm{NEt}(6.8 \mu \mathrm{L}, 39 \mu \mathrm{mol})$ was then added and the mixture was allowed to warm to room temperature over 10 minutes. After 2 hour at room temperature, TLC showed there still have baseline material, so more $\operatorname{Pr}_{2} \mathrm{NEt}(7 \mu \mathrm{L})$ was added. After $1 \mathrm{~h}$ the mixture was concentrated under reduced pressure and purified by chromatography on silica eluting with PE-EtOAc (1:1.5) to give MGSTA-19 (4.7 mg) and MGSTA-18 (8.5 $\mathrm{mg}$ ) in $65 \%$ yield for 2 steps.

Analytical data for 4-((S)-5-((2R,3E,5R,6S,7S,8Z,12Z)-6-hydroxy-7methoxy-3,5-dimethyl-14-oxooxacyclotetradeca-3,8,12-trien-2-yl)-4oxohexyl)piperidine-2,6-dione (MGSTA-18): ${ }^{1} \mathrm{H}$ NMR (500 MHz), $\delta$ 7.70 (br s, $1 \mathrm{H}$ ), 6.23 (ddd, $1 \mathrm{H}, \mathrm{J}=11 \mathrm{~Hz}, 11 \mathrm{~Hz}, 6.5 \mathrm{~Hz}, \mathrm{CH}=\mathrm{CHC}=\mathrm{O}$, H-3), 5.78 (ddd, $1 \mathrm{H}, \mathrm{J}=11 \mathrm{~Hz}, 11 \mathrm{~Hz}, 5.3 \mathrm{~Hz}, \mathrm{H}-8$ ), 5.72 (d, $1 \mathrm{H}, \mathrm{J}=$ $11.4 \mathrm{~Hz}, \mathrm{H}-4), 5.55$ (apt t, $1 \mathrm{H}, \mathrm{J}=10.5 \mathrm{~Hz}, \mathrm{H}-7$ ), $5.51(\mathrm{~d}, 1 \mathrm{H}, \mathrm{J}=10 \mathrm{~Hz}$, $\mathrm{H}-11), 5.39(\mathrm{~d}, 1 \mathrm{H}, \mathrm{J}=11.0 \mathrm{~Hz}, \mathrm{CHOC}=\mathrm{O}), 3.79(\mathrm{~d}, 1 \mathrm{H}, \mathrm{J}=10.1 \mathrm{~Hz})$, 3.19 (s, $3 \mathrm{H}$ ), 3.04 (t, $1 \mathrm{H}, \mathrm{J}=10.2 \mathrm{~Hz}, 10.2 \mathrm{~Hz}$ ), 3.00 (dd, $1 \mathrm{H}, \mathrm{J}=11.1$ $\mathrm{Hz}, 7.1 \mathrm{~Hz}), 2.80-2.68(\mathrm{~m}, 4 \mathrm{H}), 2.52(\mathrm{dt}, 2 \mathrm{H}, \mathrm{J}=6.9 \mathrm{~Hz}, 6.8 \mathrm{~Hz}, 3.3 \mathrm{~Hz})$, 2.30-2.19 (m, $2 \mathrm{H}), 2.17-2.06(\mathrm{~m}, 3 \mathrm{H}), 1.96(\mathrm{~m}, 1 \mathrm{H}), 1.63(\mathrm{~d}, 3 \mathrm{H}, \mathrm{J}=$ $1.0 \mathrm{~Hz}), 1.65-1.60(\mathrm{~m}, 2 \mathrm{H}), 1.40-1.33(\mathrm{~m}, 2 \mathrm{H}), 1.08(\mathrm{~d}, 3 \mathrm{H}, \mathrm{J}=6.6 \mathrm{~Hz})$, $0.97(\mathrm{~d}, 3 \mathrm{H}, \mathrm{J}=7.1 \mathrm{~Hz}) ;{ }^{13} \mathrm{C} \mathrm{NMR}(125 \mathrm{MHz}), \delta 210.9(\mathrm{C}), 171.7(\mathrm{C})$, $165.5(\mathrm{C}), 145.1(\mathrm{CH}), 139.6(\mathrm{CH}), 133.7(\mathrm{CH}), 129.5(\mathrm{C}), 127.0(\mathrm{CH})$, $121.4(\mathrm{CH}), 81.7(\mathrm{CH}), 77.2(\mathrm{CH}), 73.1(\mathrm{CH}), 54.9(\mathrm{CH} 3), 46.6(\mathrm{CH}), 41.3$ $(\mathrm{CH} 2), 37.7(\mathrm{CH} 2), 35.9(\mathrm{CH}), 34.2(\mathrm{CH} 2), 30.4(\mathrm{CH}), 29.8(\mathrm{CH} 2), 28.3$ (CH2), $20.1(\mathrm{CH} 2), 17.2(\mathrm{CH} 3), 13.4(\mathrm{CH} 3), 10.5(\mathrm{CH} 3)$; ESI/MS- $(\mathrm{m} / \mathrm{z})$ :
$512.26\left(\mathrm{M}_{+} \mathrm{Na}^{+}\right), 488.27\left(\mathrm{M}-\mathrm{H}^{-}\right)$; HRMS-ESI: calcd for $\mathrm{C}_{27} \mathrm{H}_{39} \mathrm{NO}_{7} \mathrm{Na}$ : 512.2624, Found: 512.2598 .

Analytical data for 4-((S)-5-((2R,3E,5R,6S,7S,8Z,12E)-6-hydroxy-7methoxy-3,5-dimethyl-14-oxooxacyclotetradeca-3,8,12-trien-2-yl)-4oxohexyl)piperidine-2,6-dione (MGSTA-19): ${ }^{1} \mathrm{H}$ NMR (500 MHz), $\delta$ 7.75 (br s, $1 \mathrm{H}, \mathrm{NH}$ ), 6.84 (ddd, $1 \mathrm{H}, \mathrm{J}=15.5 \mathrm{~Hz}, 6.0 \mathrm{~Hz}, 7.0 \mathrm{~Hz}$, $\mathrm{CH}=\mathrm{CHC}=\mathrm{O}, \mathrm{H}-3), 5.85(\mathrm{~d}, 1 \mathrm{H}, \mathrm{J}=15.5 \mathrm{~Hz}, \mathrm{CH}=\mathrm{CHC}=\mathrm{O}, \mathrm{H}-2), 5.69$ (ddd, $1 \mathrm{H}, \mathrm{J}=11 \mathrm{~Hz}, 11 \mathrm{~Hz}, 5.5 \mathrm{~Hz}, \mathrm{H}-6$ ), 5.59 (dd, $1 \mathrm{H}, \mathrm{J}=11 \mathrm{~Hz}, 9.5$ $\mathrm{Hz}, \mathrm{H}-7), 5.34\left(\mathrm{~d}, 1 \mathrm{H}, \mathrm{J}=10.0 \mathrm{~Hz}, \mathrm{CH}_{3} \mathrm{C}=\mathrm{CH}, \mathrm{H}-11\right), 5.24(\mathrm{~d}, 1 \mathrm{H}, \mathrm{J}=$ $10.4 \mathrm{~Hz}, \mathrm{CH}-\mathrm{O}-\mathrm{C}=\mathrm{O}, \mathrm{H}-13) ;{ }^{13} \mathrm{C}-\mathrm{NMR}(125 \mathrm{MHz}), \delta 211.1$ (C), 171.8 (C), $167.0(\mathrm{C}), 150.7(\mathrm{CH}), 136.2(\mathrm{CH}), 133.1(\mathrm{CH}), 131.6(\mathrm{C}), 127.8(\mathrm{CH})$, $123.0(\mathrm{CH}), 82.7(\mathrm{CH}), 77.5(\mathrm{CH}), 74.8(\mathrm{CH}), 55.5(\mathrm{CH}), 47.2(\mathrm{CH}), 41.1$ (CH2), $37.73(\mathrm{CH} 2), 37.72(\mathrm{CH} 2), 35.6(\mathrm{CH}), 34.0(\mathrm{CH} 2), 30.4(\mathrm{CH} 2)$, $30.3(\mathrm{CH}), 29.3(\mathrm{CH} 2), 20.0(\mathrm{CH} 2), 17.6(\mathrm{CH} 3), 13.5(\mathrm{CH} 3), 11.4(\mathrm{CH} 3)$;

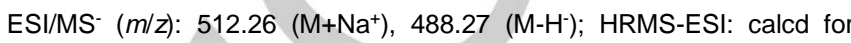
$\mathrm{C}_{27} \mathrm{H}_{39} \mathrm{NO}_{7} \mathrm{Na}: 512.2624$, Found: 512.2621 .

Cell viability assay (MTT-assay): Cell viability (metabolic activity of viable cells) was quantified by MTT assay. Cells were seeded onto 96well plate (Nunc Inc., Denmark) at the concentration of $1 \times 10^{4}$ cells per well. When cells reached $60-70 \%$ confluence, the medium (DMEM) was replaced with medium containing $10 \%$ FBS and six various migrastatin analogues at the concentrations of: 1,10 or $100 \mu \mathrm{M}$. The cultures were incubated for 24 hours. Then, cells were incubated with $0.5 \mathrm{mg} / \mathrm{ml}$ tetrazolium salt MTT diluted in phenol red-free DMEM medium (Sigma Aldrich) for $4 \mathrm{~h}$ at $37^{\circ} \mathrm{C}$. To complete solubilization of the formazan crystals, $100 \mu \mathrm{l}$ of DMSO (Dimethyl sulfoxide, Sigma Aldrich) were added to each well. Cell viability was quantified by measuring photometric absorbance at $570 \mathrm{~nm}$ in a multi-well plate reader (Infinite 200 PRO Tecan $^{\mathrm{TM}}$, TECAN, Switzerland). All the samples were examined in triplicate, each experiment was conducted three times $(n=9)$.

In vitro wound healing assay (scratch test): the scratch assay was conducted to assess the influence of migrastatin analogues on MCF7, MCF7-Dox, MDA-MB361, MDA-MB231, HPAC cancer cell motility. The cells were seeded in a high density at $600 \mathrm{~mm}$ Petri dishes (CorningCostar, Cambridge, USA). After $24 \mathrm{hrs,} \mathrm{the} \mathrm{medium} \mathrm{was} \mathrm{removed} \mathrm{and}$ replaced with medium (DMEM) containing 10\% FBS and one migrastatin analogues or DMSO (control). The monolayer was wounded by scratching the surface: as uniformly and straight as possible with a pipette tip $(1000 \mu \mathrm{l})$ at least three times. The images of cells invading the scratch were captured at indicated time points $(0,6$ and 24 or $48 \mathrm{hrs}$ where indicated) using phase contrast microscopy (IX 70 Olympus Optical Co., Germany). The pictures were analyzed using a computerassisted image analyzer (Olympus Microimage ${ }^{\mathrm{TM}}$ Image Analysis, software version 4.0 for Windows, USA). The migration rate was expressed as percentage of scratch closure and was calculated as follows: $\%$ of scratch closure $=a-b / a$, where $(a)$ is a distance between edges of the wound, and (b) is the distance which remained cell-free during cell migration to close the wound ${ }^{[39]}$. The values are presented as means of three independent wound fields from three independent experiments $(n=9)$.

Trans-well migration assay: The Boyden chamber cell migration assay was performed using the BD Falcon ${ }^{\mathrm{TM}}$ FluoroBlock ${ }^{\mathrm{TM}}$ 24-Multiwell Insert Plates ( 8 micron pore size) (BD Biosciences, USA). Firstly, cells $\left(1 \times 10^{5}\right)$ were suspended in FBS free medium and added to the apical chambers of an insert plates $(500 \mu \mathrm{l})$. Then $750 \mu \mathrm{l}$ of chemoattractant (10\% FBS) was added to the basal chambers. Migrastatin analogues or DMSO (as a control) were added to the medium in both chambers. For dosedependent studies MGSTA analogues were used in the range of 
concentration from 0.01 to $100 \mu \mathrm{M}$. Migration assays were carried out for $18-20 \mathrm{~h}$ at standard culture conditions. Then, medium was carefully removed from apical chamber and the insert system was transferred into a second 24-well plate containing $500 \mu \mathrm{l}$ of $2.5 \mu \mathrm{g} / \mathrm{ml}$ Calcein AM in Hanks' Balanced Salt solution (HBSS). Plates were incubated for one hour at standard culture conditions. Then, the fluorescence of migrated cells was measured at excitation wavelength $485 \mathrm{~nm}$ and emission wavelength $530 \mathrm{~nm}$ using florescent plate reader with bottom reading capabilities Infinite 200 PRO Tecan ${ }^{\text {TM }}$ (TECAN, Switzerland). All samples were assayed in triplicate, and each experiment was conducted three times $(n=9)$. For each experiment two negative controls were used: (1) cells grown as given above without adding chemoattractant to the medium, and (2) medium added as described without cells. In order to determine fluorescence of cells that migrated through the membrane, plates were analysed using a fluorescence microscope (Olympus BX60, magnification $\mathrm{x} 4$ ).

In vitro pharmacology: Binding assays: Cell membrane homogenates are incubated with radioligand binding in the absence or presence of MGSTA-6 in a buffer. Non specific binding is determined in the presence of a specific agonist or antagonist at the target. Following incubation, the samples are filtered rapidly under vacuum through glass fiber filters presoaked in a buffer and rinsed several times with an ice-cold buffer using a 96-sample cell harvester. The filters are dried then counted for radioactivity in a scintillation counter using a scintillation cocktail. The results are expressed as a percent inhibition of the control radioligand specific binding. ${ }^{[40]}$

\section{Acknowledgements}

This work was supported by Science Foundation Ireland (grant Nos. 07/IN.1/B966 and 11/TIDA/B2047) and by National Science Center (grant no. 2013/09/D/NZ5/02496). The research leading to these results also received funding from the People Programme (Marie Curie Actions) of the European Union's Seventh Framework Programme (FP7/2007-2013) under grant agreement number PIEF-GA-2011-299042. We are very grateful to Dr. Alexandre Calon and Dr. Enza Lonardo (Institute for Research in Biomedicine, IRB Barcelona) for helpful discussion.

Keywords: • Glycosidation; • Anomerization $\bullet$ Stereoselective Synthesis - Natural Products; $\bullet$ Tumour cell migration.

[1] H. Yamaguchi, J. Wyckoff, J. Condeelis, Current opinion in cell biology 2005, 17, 559-564.

[2] G. Fenteany, S. Zhu, Curr Top Med Chem 2003, 3, 593-616.

[3] B. D. Hedley, E. Winquist, A. F. Chambers, Expert Opinion on Therapeutic Targets 2004, 8, 527-536.

[4] B. N. Goguen, B. Imperiali, ACS Chem Biol 2011, 6, 1164-1174.

[5] J.-Y. Wach, K. Gademann, Synlett 2012, 2012, 163-170.

[6] C. Gaul, J. T. Njardarson, D. Shan, D. C. Dorn, K.-D. Wu, W. P. Tong, X.-Y. Huang, M. A. S. Moore, S. J. Danishefsky, Journal of the American Chemical Society 2004, 126, 11326-11337.

[7] D. Shan, L. Chen, J. T. Njardarson, C. Gaul, X. Ma, S. J. Danishefsky, X. Y. Huang, Proceedings of the National Academy of Sciences of the United States of America 2005, 102, 3772-3776. Yang, O. Ouerfelli, D. Xiao, M. A. S. Moore, J. Massagué, S. J. Danishefsky, Journal of the American Chemical Society 2010, 132, 3224-3228.
K. Majchrzak, D. Lo Re, M. Gajewska, M. Bulkowska, A. Homa, K. Pawlowski, T. Motyl, P. V. Murphy, M. Krol, PloS one 2013, 8 , e76789.

D. Lo Re, Y. Zhou, M. Nobis, K. I. Anderson, P. V. Murphy, Chembiochem : a European journal of chemical biology 2014, 15, 1459-1464.

D. Vergara, P. Simeone, P. del Boccio, C. Toto, D. Pieragostino, A. Tinelli, R. Acierno, S. Alberti, M. Salzet, G. Giannelli, P. Sacchetta, M. Maffia, Molecular BioSystems 2013, 9, 1127-1138.

H. Yamaguchi, T. Inoue, T. Eguchi, Y. Miyasaka, K. Ohuchida, K. Mizumoto, T. Yamada, K. Yamaguchi, M. Tanaka, M. Tsuneyoshi, Mod Pathol 2007, 20, 552-561.

D. Vignjevic, M. Schoumacher, N. Gavert, K.-P. Janssen, G. Jih, M. Laé, D. Louvard, A. Ben-Ze'ev, S. Robine, Cancer Research 2007, 67, 6844-6853.

H. Ghebeh, S. Al-Khaldi, S. Olabi, A. Al-Dhfyan, F. Al-Mohanna, R. Barnawi, A. Tulbah, T. Al-Tweigeri, D. Ajarim, M. Al-Alwan, Br J Cancer 2014, 111, 1552-1561.

Y. Kanda, T. Kawaguchi, Y. Kuramitsu, T. Kitagawa, T. Kobayashi, N. Takahashi, H. Tazawa, H. Habelhah, J. Hamada, M. Kobayashi, M. Hirahata, K. Onuma, M. Osaki, K. Nakamura, M. Hosokawa, F. Okada, Proteomics 2014, 14, 1031-1041.

a) P. Nagorny, I. Krauss, J. T. Njardarson, L. Perez, C. Gaul, G. Yang, O. Ouerfelli, S. J. Danishefsky, Tetrahedron Lett 2010, 51, 3873-3875; b) N. Lecomte, J. T. Njardarson, P. Nagorny, G. Yang, R. Downey, O. Ouerfelli, M. A. Moore, S. J. Danishefsky, Proceedings of the National Academy of Sciences of the United States of America 2011, 108, 15074-15078.

a) N. R. Gade, J. Iqbal, Tetrahedron Letters 2013, 54, 4225-4227; b) L. C. Dias, F. G. Finelli, L. S. Conegero, R. Krogh, A. D. Andricopulo, European Journal of Organic Chemistry 2010, 2010, 6748-6759; c) S. R. Rajski, B. Shen, Chembiochem : a European journal of chemical biology 2010, 11, 1951-1954; d) J. Ju, S. R. Rajski, S.-K. Lim, J.-W. Seo, N. R. Peters, F. M. Hoffmann, B. Shen, Journal of the American Chemical Society 2009, 131, 13701371; e) J. Yadav, P. Lakshmi, Synlett 2010, 2010, 1033-1036; f) S. Reymond, J. Cossy, Comptes Rendus Chimie 2008, 11, 14471462; g) S. Reymond, J. Cossy, Tetrahedron 2007, 63, 5918-5929; h) C. Gaul, J. T. Njardarson, S. J. Danishefsky, Journal of the American Chemical Society 2003, 125, 6042-6043; i) C. Gaul, S. J. Danishefsky, Tetrahedron Letters 2002, 43, 9039-9042; j) S. Reymond, J. Cossy, European Journal of Organic Chemistry 2006, 2006, 4800-4804; k) V. Sai Baba, P. Das, K. Mukkanti, J. Iqbal, Tetrahedron Letters 2006, 47, 6083-6086.

a) G. Anquetin, S. L. Rawe, K. McMahon, E. P. Murphy, P. V. Murphy, Chemistry - A European Journal 2008, 14, 1592-1600; b) J. Ju, S. R. Rajski, S. K. Lim, J. W. Seo, N. R. Peters, F. M. Hoffmann, B. Shen, Bioorganic \& medicinal chemistry letters 2008, 18, 5951-5954

L. Chen, S. Yang, J. Jakoncic, J. J. Zhang, X. Y. Huang, Nature 2010, 464, 1062-1066.

0] Y. Rao, X. Li, P. Nagorny, J. Hayashida, S. J. Danishefsky, Tetrahedron Lett 2009, 50, 6684-6686. 2005, 127, 11930-11931.

[22] S. J. Danishefsky, M. Mandal, D. C. Dorn, M. A. S. Moore, PCT/US2005/034305, 2006

[23] H. C. Brown, K. S. Bhat, J Am Chem Soc 1986, 108, 293-294. 
[24] a) K. Ando, The Journal of Organic Chemistry 1998, 63, 84118416; b) K. Ando, T. Oishi, M. Hirama, H. Ohno, T. Ibuka, The Journal of Organic Chemistry 2000, 65, 4745-4749.

[25] H. Fuwa, N. Yamagata, A. Saito, M. Sasaki, Organic Letters 2013, 15, 1630-1633.

[26] M. Shipkova, E. Wieland, Clinica chimica acta; international journal of clinical chemistry 2005, 358, 2-23.

[27] A. V. Stachulski, X. Meng, Natural product reports 2013, 30, 806 848.

[28] a) M. Trellu, A. Filali-Ansary, D. Françon, R. Adam, P. Lluel, C. Dubruc, J. P. Thénot, Fundamental \& Clinical Pharmacology 2004, 18, 493-501; b) M. Shipkova, V. W. Armstrong, M. Oellerich, E. Wieland, Ther Drug Monit 2003, 25, 1-16; c) J. K. Ritter, ChemicoBiological Interactions 2000, 129, 171-193; d) H. Kroemer, U. Klotz, Clin. Pharmacokinet. 1992, 23, 292-310.

[29] G. J. Kilpatrick, T. W. Smith, Medicinal Research Reviews 2005 , 25, 521-544.

[30] M. van Heek, C. Farley, D. S. Compton, L. Hoos, K. B. Alton, E. J. Sybertz, H. R. Davis, British Journal of Pharmacology 2000, 129 1748-1754.

[31] A. El Alaoui, F. Schmidt, C. Monneret, J.-C. Florent, The Journal of Organic Chemistry 2006, 71, 9628-9636.

[32] K. Shimawaki, Y. Fujisawa, F. Sato, N. Fujitani, M. Kurogochi, H. Hoshi, H. Hinou, S.-I. Nishimura, Angewandte Chemie International Edition 2007, 46, 3074-3079.

[33] a) C. O'Brien, M. Poláková, N. Pitt, M. Tosin, P. V. Murphy, Chemistry - A European Journal 2007, 13, 902-909; b) W. Pilgrim, P. V. Murphy, Organic Letters 2009, 11, 939-942; c) C. O'Reilly, P. V. Murphy, Organic Letters 2011, 13, 5168-5171; d) M. Farrell, J. Zhou, P. V. Murphy, Chemistry - A European Journal 2013, 19 14836-14851; e) W. Pilgrim, P. V. Murphy, The Journal of Organic Chemistry 2010, 75, 6747-6755.

[34] a) Y. Ishikawa, M. Tachibana, C. Matsui, R. Obata, K. Umezawa, S. Nishiyama, Bioorganic \& medicinal chemistry letters 2009, 19 1726-1728; b) T. Miyazaki, Y. Han-ya, H. Tokuyama, T. Fukuyama Synlett 2004, 2004, 477-480.

[35] I. J. Krauss, M. Mandal, S. J. Danishefsky, Angew Chem Int Ed Eng/ 2007, 46, 5576-5579.

[36] a) P. A. Kenny, G. Y. Lee, C. A. Myers, R. M. Neve, J. R. Semeiks, P. T. Spellman, K. Lorenz, E. H. Lee, M. H. Barcellos-Hoff, O. W Petersen, J. W. Gray, M. J. Bissell, Molecular oncology 2007, 1, 84-96; b) G. M. Nagaraja, M. Othman, B. P. Fox, R. Alsaber, C. M Pellegrino, Y. Zeng, R. Khanna, P. Tamburini, A. Swaroop, R. P. Kandpal, Oncogene 2005, 25, 2328-2338.

[37] Y. Hashimoto, M. Parsons, J. C. Adams, Molecular Biology of the Cell 2007, 18, 4591-4602.

[38] J. Bowes, A. J. Brown, J. Hamon, W. Jarolimek, A. Sridhar, G. Waldron, S. Whitebread, Nature reviews. Drug discovery 2012, 11, 909-922.

[39] L. G. Rodriguez, X. Wu, J. L. Guan, Methods Mol Biol 2005, 294 23-29.

[40] T. P. Kenakin, Pharmacologic analysis of drug-receptor interaction, 2nd ed., Raven, New York, 1993. 
Entry for the Table of Contents (Please choose one layout)

Layout 1:

\section{FULL PAPER}

Text for Table of Contents

Layout 2:

\section{FULL PAPER}

Author(s), Corresponding Author(s)*

Page No. - Page No.

Title

((Insert TOC Graphic here: max. width: $5.5 \mathrm{~cm}$; max. height: $5.0 \mathrm{~cm})$ )
((Insert TOC Graphic here; max. width: $11.5 \mathrm{~cm}$; max. height: $2.5 \mathrm{~cm})$ )

Text for Table of Contents
Author(s), Corresponding Author(s)*

Page No. - Page No.

Title 